\title{
Multiple Sulfur Isotope Geochemistry during the Permian-Triassic Transition
}

\author{
Masafumi Saitoh (D)
}

Citation: Saitoh, M. Multiple Sulfur Isotope Geochemistry during the Permian-Triassic Transition. Geosciences 2021, 11, 327. https:// doi.org/10.3390/geosciences11080327

Academic Editors: Jesus MartinezFrias and Henrik Drake

Received: 7 July 2021

Accepted: 29 July 2021

Published: 1 August 2021

Publisher's Note: MDPI stays neutral with regard to jurisdictional claims in published maps and institutional affiliations.

Copyright: (C) 2021 by the author. Licensee MDPI, Basel, Switzerland. This article is an open access article distributed under the terms and conditions of the Creative Commons Attribution (CC BY) license (https:// creativecommons.org/licenses/by/ $4.0 /)$.
School of Geosciences and Civil Engineering, Kanazawa University, Kanazawa 920-1192, Japan; msaitoh@se.kanazawa-u.ac.jp

\begin{abstract}
The end-Permian mass extinction was the largest biodiversity crisis in the Phanerozoic. Based on characteristic negative $\Delta^{33} \mathrm{~S}$ signals of sedimentary pyrite, previous multiple sulfur isotope studies suggested shoaling of anoxic/sulfidic deep-waters onto a shelf, leading to the shallowmarine extinction. However, the validity of this shoaling model has been controversial. I compiled previously-reported multiple sulfur isotope records during the Permian-Triassic transition interval, and examined a stratigraphic relationship between the extinction horizon, redox oscillation in the depositional settings, and the multiple sulfur isotope record in each studied section. The compilation shows that the negative $\Delta^{33} \mathrm{~S}$ signals do not correspond clearly to the extinction horizon or to the benthic anoxia/euxinia in the studied sections. The compilation also documents that the multiple sulfur isotope records during the Permian-Triassic transition are substantially variable, and that the negative $\Delta^{33} \mathrm{~S}$ signals were observed in various types of sediments including shallow-marine carbonates, carbonates/siltstones of relatively deep-water facies, and abyssal deep-sea cherts. Those observations allow me to infer that the negative $\Delta^{33} \mathrm{~S}$ signal is not a robust indicator of shoaling. Rather, this isotopic signal may reflect substantial sulfur isotope heterogeneity in the sediments controlled by local factors.
\end{abstract}

Keywords: Permian-Triassic transition interval; triple extinction; multiple sulfur isotopes; deep-water shoaling; bioturbation; local sulfur isotope heterogeneity

\section{Introduction}

The end-Permian mass extinction was the largest biodiversity decline in the Phanerozoic (e.g., [1]). Although the major extinction across the Permian-Triassic boundary (P-TB) (ca. 251.9 Ma) has been extensively studied since the 1980s (e.g., [2,3]), numerous studies revealed repeated biotic crises with protracted environmental deterioration during the Permian-Triassic transition interval (Figure 1a) (e.g., [4-6]), including the end-Guadalupian (Middle Permian) extinction (ca. 259.5 Ma) [7-9], and biotic upheavals in the Early Triassic (ca. 251.9 to $246.7 \mathrm{Ma}$ ) [10] with the extinction immediately before the Smithian-Spathian boundary (S-SB; ca. 250.6 Ma) in the Olenekian (Late Early Triassic) (e.g., [11,12]). Several geologic events around the Guadalupian-Lopingian (Late Permian) boundary (G-LB) have been proposed as the cause of the end-Guadalupian extinction, such as the eruption of the Emeishan flood basalts (e.g., [13,14]), a eustatic sea-level fall [7], a global cooling [15], and oceanic anoxia/euxinia [16-18]. As the cause of the P-TB extinction, a number of geologic phenomena have been proposed, including a bolide impact (e.g., [19]), volcanism of the Siberian Traps Large Igneous Province (STLIP) (e.g., $[20,21])$ concurrent with climate warming (e.g., [22]), anoxia/euxinia (e.g., [23,24]), hypercapnia [25], and oceanic acidification (e.g., [26]).

Previous studies also revealed biotic upheavals following the P-TB extinction in the Early Triassic (Figure 1a), which were presumably driven by sustained environmental stresses in this interval, such as recurrent STLIP volcanism (e.g., [27]), elevated $p \mathrm{CO}_{2}$ (e.g., [28-30]) and $\mathrm{pCH}_{4}$ (e.g., [31,32]), global warming [33], and ocean acidification [34] 
and anoxia (e.g., [10,35-37]). Especially, the late-Smithian extinction event was one of the severest biodiversity crises during the delayed recovery interval of the Early Triassic (Figure 1a) (e.g., [11]), and was characterized by a turnover in marine fauna including ammonoids, conodonts, and other invertebrates (e.g., [38,39]), and by a change in terrestrial ecosystems [11]. Previous studies suggested that the late-Smithian extinction generally coincided with several geologic events, such as the recurrent STLIP activity [40], large carbon cycle fluctuations [11,41], and extreme greenhouse conditions (late Smithian Thermal Maximum) [33,42] followed by a major cooling around the S-SB associated with ocean anoxia [12,43] and/or acidification [34]. Nevertheless, the ultimate trigger mechanisms of the "triple" extinction during the Permian-Triassic transition are not yet fully understood and are still hotly debated (e.g., [3,44]).

Multiple sulfur isotope geochemistry is useful for tracking the global sulfur cycle through Earth history (e.g., [45,46]). Several previous studies analyzed multiple sulfur isotopes in sedimentary records in the Permian-Triassic transition interval (Figure 1b), and tried to reconstruct the sedimentary sulfur cycle in association with bottom water redox conditions and benthos activity during the three extinction events. In particular, based on an anomalous sulfur isotopic signal observed in the analyzed sediments, initial studies proposed shoaling of anoxic/sulfidic deep-waters onto a shelf, leading to the shallowmarine extinction. However, the validity of this shoaling model has been questioned by later studies. In this article, I briefly review the multiple sulfur isotope system and its initial application to the Permian sedimentary records with the original shoaling models. Then, I review later multiple sulfur isotope studies in the Permian-Triassic transition interval, particularly focusing on a stratigraphic relationship between the extinction horizon, redox conditions in the depositional settings, and the multiple sulfur isotope record in each studied section. Finally, I compile all the previous multiple sulfur isotope records during the Permian-Triassic transition and examine the validity of the original shoaling models.

a

Permian-Triassic transition interval

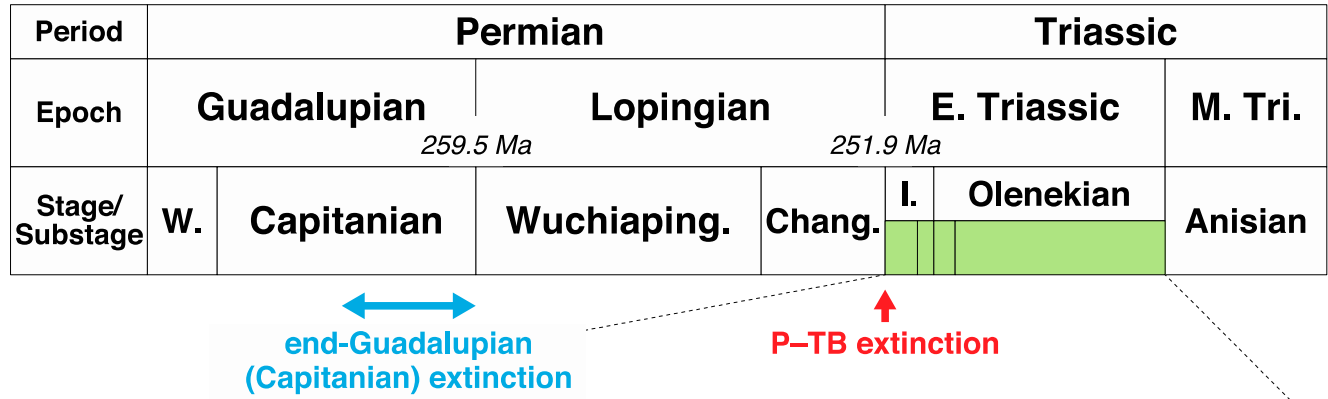

\begin{tabular}{|c|c|c|c|}
\hline \multicolumn{4}{|c|}{ E. Triassic } \\
\hline \multicolumn{2}{|c|}{ Induan } & $250.6 \mathrm{Ma}$ & Olenekian \\
\hline Gries. & D. & Smith. & Spathian \\
\hline
\end{tabular}

late-Smithian extinction

Figure 1. Cont. 


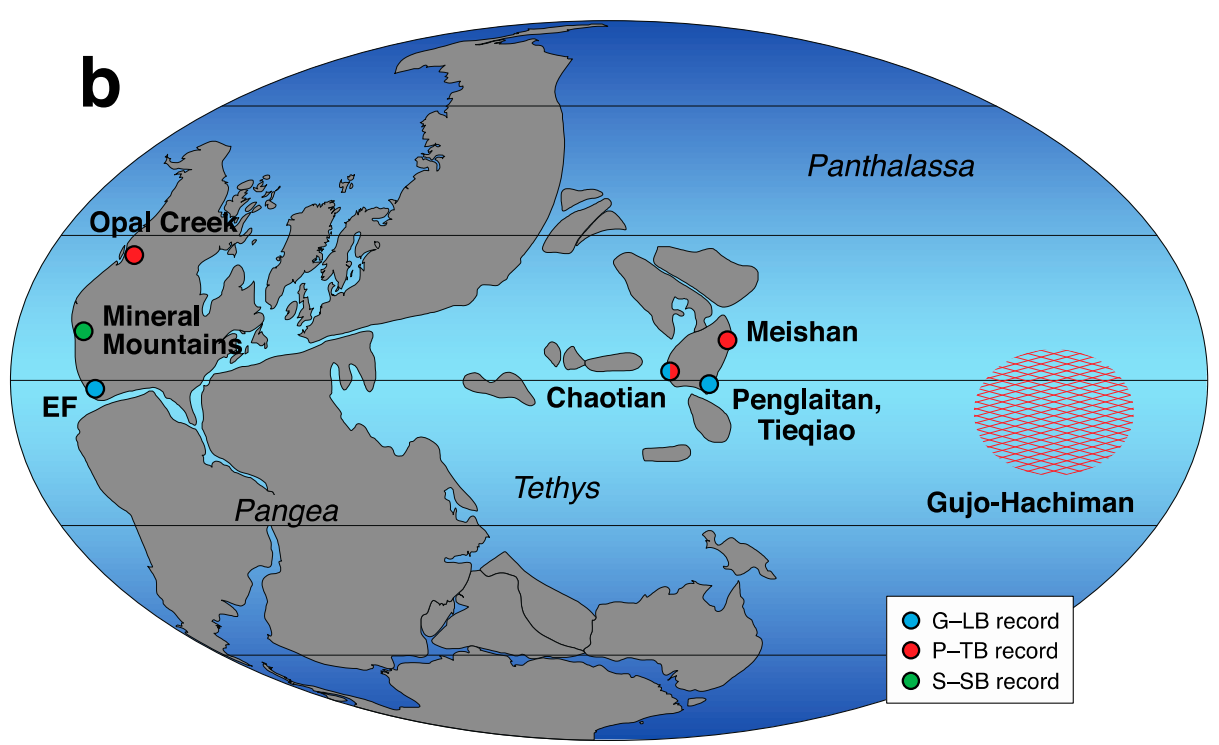

Figure 1. The Permian-Triassic transition interval. (a) "triple" extinction during the interval with the ages of the boundaries [47,48]; (b) paleo-geographic map [49] with sections of previous multiple sulfur isotope studies. The location of Gujo-Hachiman in mid-Panthalassa is not well constrained. E. Triassic: Early Triassic, M. Tri.: Middle Triassic, W.: Wordian, Wuchiaping.: Wuchiapingian, Chang.: Changhsingian, I.: Induan, Gries.: Griesbachian, D.: Dienerian, Smith.: Smithian.

\section{Multiple Sulfur Isotope Geochemistry and Its Initial Application to the Permian Sedimentary Records}

\subsection{Multiple Sulfur Isotope System}

Sulfur has four stable isotopes $\left({ }^{32} \mathrm{~S},{ }^{33} \mathrm{~S},{ }^{34} \mathrm{~S}\right.$, and $\left.{ }^{36} \mathrm{~S}\right)$, and the sulfur isotopic composition of sulfur-bearing material is described conventionally using delta notation:

$$
\delta^{\mathrm{x}} \mathrm{S}=\left(\left({ }^{\mathrm{x}} \mathrm{S} /{ }^{32} \mathrm{~S}\right)_{\text {sample }} /\left({ }^{\mathrm{x}} \mathrm{S} /{ }^{32} \mathrm{~S}\right)_{\text {reference }}-1\right) \times 1000(\mathrm{x}=33,34 \text {, or } 36),
$$

where $\left({ }^{\mathrm{x}} \mathrm{S} /{ }^{32} \mathrm{~S}\right)_{\text {sample }}$ and $\left({ }^{\mathrm{x}} \mathrm{S} /{ }^{32} \mathrm{~S}\right)_{\text {reference }}$ are the isotope ratios of sample and reference material, respectively. For the multiple sulfur isotope systematics, capital delta notation is generally used to describe a deviation from a mass-dependent fractionation (MDF) relationship, according to the following formulas [50]:

$$
\Delta^{33} S=\delta^{33} S-\left(\left(1+\delta^{34} S / 1000\right)^{0.515}-1\right) \times 1000,
$$

and

$$
\Delta^{36} S=\delta^{36} S-\left(\left(1+\delta^{34} S / 1000\right)^{1.90}-1\right) \times 1000 .
$$

The $\delta^{34} S, \Delta^{33} S$, and $\Delta^{36} S$ values are reported in \%o relative to the Vienna Cañon Diablo Troilite (V-CDT) standard.

Multiple sulfur isotope geochemistry has been a useful tool for understanding the sulfur cycle in the Archean [51], as Archean sedimentary records are characterized by their unique isotopic signals of mass-independent fractionation of sulfur (S-MIF) with substantially large $\Delta^{33} S$ (up to $+15 \%$ ). Photochemical reactions of sulfur dioxide in the reducing atmosphere have been a leading candidate for the main S-MIF yielding mechanism for the Archean records ([52] and references therein). After the Great Oxidation Event at ca. $2.3 \mathrm{Ga}$, the $\Delta^{33} \mathrm{~S}$ values of Proterozoic and Phanerozoic sediments are substantially small (generally within $0 \pm 0.2 \%$ ). [46,52]. However, in many cases, the $\Delta^{33} S$ values of the younger sediments deviate slightly but significantly from zero. These nonzero $\Delta^{33} \mathrm{~S}$ records in the Proterozoic and Phanerozoic, which are detectable by high-precision multiple sulfur isotope measurements using a fluorination technique, most likely reflected MDF processes in the oceanic biogeochemical cycles (e.g., [53]). 
Sulfur isotope fractionation during a MDF process, such as microbial sulfate reduction (MSR), can be described generally by the ${ }^{34} \varepsilon$ and ${ }^{33} \lambda$ values [54]:

$$
{ }^{34} \varepsilon=\left(1-\left({ }^{34} S /{ }^{32} S\right)_{\text {product }} /\left({ }^{34} \mathrm{~S} /{ }^{32} \mathrm{~S}\right)_{\text {reactant }}\right) \times 1000,
$$

and

$$
{ }^{33} \lambda=\ln \left[\left({ }^{33} \mathrm{~S} /{ }^{32} \mathrm{~S}\right)_{\text {product }} /\left({ }^{33} \mathrm{~S} /{ }^{32} \mathrm{~S}\right)_{\text {reactant }}\right] / \ln \left[\left({ }^{34} \mathrm{~S} /{ }^{32} \mathrm{~S}\right)_{\text {product }} /\left({ }^{34} \mathrm{~S} /{ }^{32} \mathrm{~S}\right)_{\text {reactant }}\right],
$$

where $\left({ }^{\mathrm{x}} \mathrm{S} /{ }^{32} \mathrm{~S}\right)_{\text {product }}$ and $\left({ }^{\mathrm{x}} \mathrm{S} /{ }^{32} \mathrm{~S}\right)$ reactant are the instantaneous sulfur isotope ratios of product and the remaining reactant, respectively $(x=33$ or 34$)$. The ${ }^{33} \lambda$ value is approximately 0.515 during an equilibrium exchange reaction at temperature between $0^{\circ} \mathrm{C}$ and $100{ }^{\circ} \mathrm{C}$ [50]. However, the ${ }^{33} \lambda$ value is generally lower than 0.515 during kinetic MSR, and the $\Delta^{33} S$ value of instantaneously produced hydrogen sulfide $\left(\mathrm{H}_{2} \mathrm{~S}\right)$ is higher than the value of substrate sulfate [54]. Another consequence of the multiple sulfur isotope system is a nonlinear effect of sulfur mixing on $\Delta^{33} S$ [50]. When ${ }^{34}$ S-depleted and ${ }^{34}$ S-enriched sulfur are mixed, the $\Delta^{33} S$ value of mixed sulfur is generally lower than the values of initial sulfur pools. On a $\delta^{34} S-\Delta^{33} S$ cross plot, the mixed sulfur is along a convex downward curve between the ${ }^{34}$ S-depleted and ${ }^{34}$ S-enriched endmembers, according to the mixing ratio. In particular, a negative $\Delta^{33} \mathrm{~S}$ signal cannot be produced solely via a normal kinetic process (such as MSR) but suggests a mixing of ${ }^{34}$ S-depleted and ${ }^{34}$ S-enriched sulfur [50].

\subsection{Original Shoaling Model for the P-TB Event}

Shen et al. [55] first analyzed the multiple sulfur isotopes in the end-Permian sedimentary records. They reported the quadruple sulfur isotopic composition of sedimentary pyrite in P-TB shelf carbonates/shales at Meishan in South China, the Global Stratotype Section and Point (GSSP) for the P-TB (Figure 1b) [56]. The P-TB successions at Meishan have been extensively studied and previous studies revealed multiple lines of evidence for environmental changes around the P-TB, including the abrupt extinction [2,57], sea-level changes (e.g., [58,59]), a negative carbon isotopic excursion (e.g., [57,60]), petrological and geochemical evidence for anoxia/euxinia (e.g., [58,61,62]), oxygen and calcium isotope anomalies in conodont apatite [22,63], and anomalous mercury enrichment [64]. In the analyzed P-TB interval, bedded carbonates (Beds 22-24) are overlain by several cm-thick "event beds", a gray-green ash clay bed (Bed 25) and a black organic-rich claystone bed (Bed 26). Overlying Bed 27 is composed of argillaceous wackestone and dolostone, and Bed 28 is a $~ 0.5$-cm-thick gray-green ash clay, which is overlain by carbonate-dominant Bed 29 and organic rich mudstone (Bed 30). Beds 24e-28 are particularly regarded as the "maximum extinction interval" [2], with the major extinction at Beds $24 \mathrm{e}-25$ and the second phase of extinction at Bed 28 [65]. Another biotic crisis occurred later in Beds 34-38 [66]. The P-TB is assigned within Bed 27 based on the First Appearance Datum (FAD) of conodont Hindeodus parvus, an index fossil for the base of the Triassic [56].

Shen Y. et al. [55] found negative $\Delta^{33} \mathrm{~S}$ values below the maximum extinction interval (Figure 2a). As described above, this anomalous sulfur isotopic signal is indicative of mixing of ${ }^{34} \mathrm{~S}$-depleted and ${ }^{34} \mathrm{~S}$-enriched sulfur [50]. Shen Y. et al. interpreted that the supposed ${ }^{34} \mathrm{~S}$-depleted sulfur source was $\mathrm{H}_{2} \mathrm{~S}$ produced via MSR in an open sediment with burrows under oxic conditions. Enhanced benthos activity may have supplied seawater sulfate from the overlying water column into the sediments via burrows. On the other hand, they suggested that the ${ }^{34} \mathrm{~S}$-enriched sulfur source was $\mathrm{H}_{2} \mathrm{~S}$ produced via quantitative MSR in an anoxic sediment with no burrows. A sulfate supply into the sediment may have been reduced under anoxic conditions with the absence of bioturbation, promoting quantitative MSR in the porewater within the closed sediment. Furthermore, they inferred that the supposed absence of bioturbation was caused by shoaling of anoxic deep-water onto the shallow shelf. According to their model, the bulk $\Delta^{33} \mathrm{~S}$ value of the sediment was positive under oxic conditions because ${ }^{34} \mathrm{~S}$-depleted $\mathrm{H}_{2} \mathrm{~S}$ produced within the open sediment was a predominant sulfur source for sedimentary pyrite. However, when the 
anoxic water shoaled, the shelf sediment shifted to a closed system due to the disappearance of bioturbation, and ${ }^{34} \mathrm{~S}$-enriched $\mathrm{H}_{2} \mathrm{~S}$ was newly produced in the sediment via quantitative MSR. ${ }^{34}$ S-enriched $\mathrm{H}_{2} \mathrm{~S}$ precipitated in situ as pyrite within the sediment and was mixed with the formerly produced ${ }^{34} \mathrm{~S}$-depleted pyrite, resulting in the negative $\Delta^{33} \mathrm{~S}$ value of bulk sediment. Shen Y. et al. [55] therefore concluded that the anomalous negative $\Delta^{33} \mathrm{~S}$ values indicated shoaling of anoxic deep-water, leading to the shelf extinction.
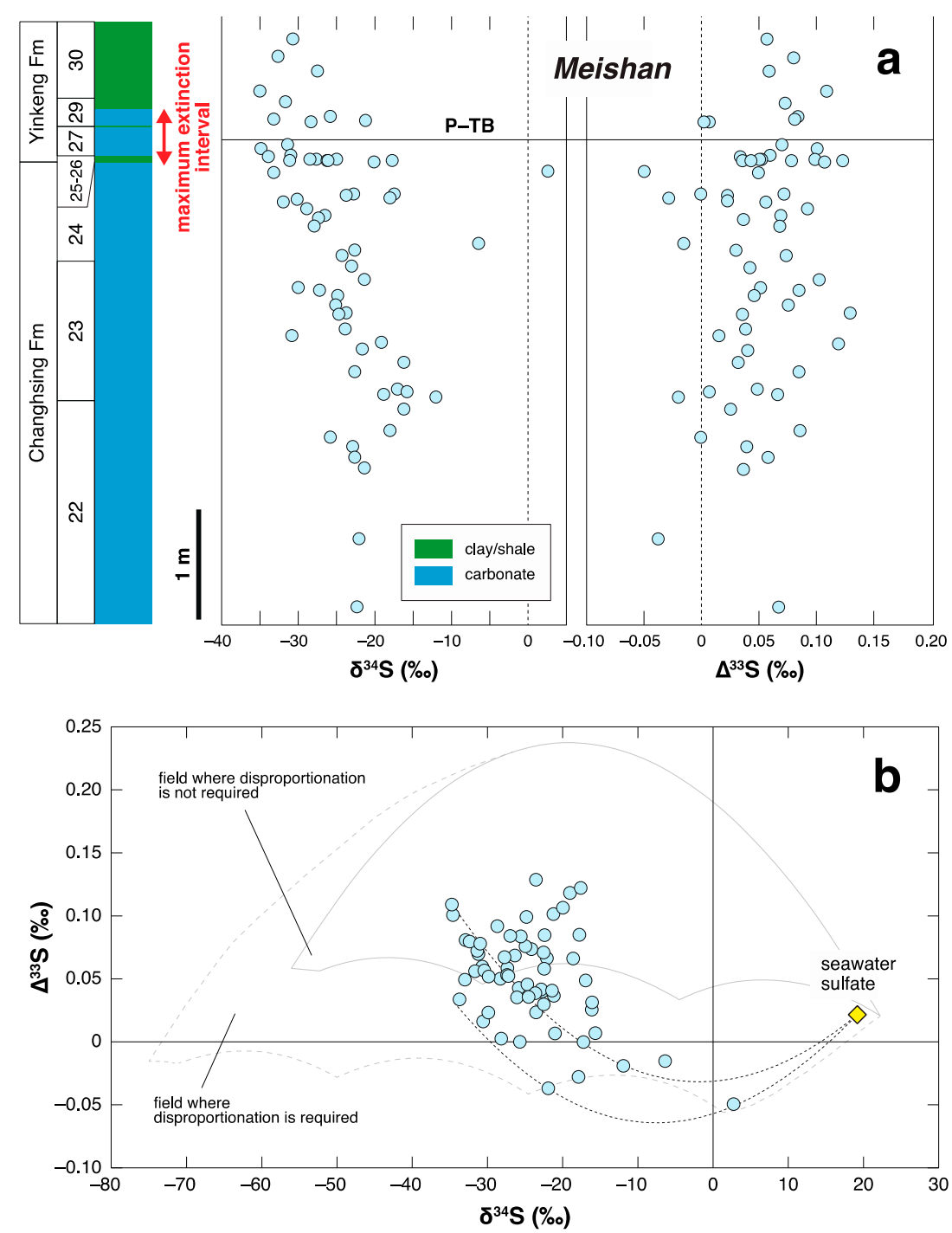

Figure 2. Multiple sulfur isotope record across the Permian-Triassic boundary (P-TB) at Meishan [55]. (a) sulfur isotope chemostratigraphy. A number along the log is Bed number. The maximum extinction interval is from Shen S.Z. et al. [2]. Fm: Formation; (b) $\delta^{34} S-\Delta^{33} S$ cross plot modified from Shen Y. et al. [55]. Most of the data with positive $\Delta^{33} S$ can be explained by microbial sulfate reduction (MSR) in sulfate-enriched sediments with burrows and/or disproportionation of sulfur intermediate compounds. In contrast, some negative $\Delta^{33} \mathrm{~S}$ values suggested the addition of ${ }^{34} \mathrm{~S}$-enriched sulfide (diamond) to the sediments, although fields where disproportionation were required and not required (dashed and solid umbrellas, respectively) were expanded later by Zhang et al. [67] and the ${ }^{34}$ S-enriched sulfide's participation in the sediments with negative $\Delta^{33} \mathrm{~S}$ value became unclear. Shen Y. et al. [55] interpreted that the ${ }^{34} \mathrm{~S}$-enriched sulfide was produced via quantitative reduction of porewater sulfate in the closed sediments with the absence of bioturbation, and that its $\delta^{34} \mathrm{~S}$ and $\Delta^{33} S$ values were identical to the values of contemporaneous seawater sulfate $(+19.2 \%$ and $+0.022 \%$, respectively) [68]. A convex downward curve is a possible mixing trend. Shen Y. et al. further inferred that shoaling of anoxic deep-water onto the shelf reduced the benthos activity and led to the production of ${ }^{34}$ S-enriched sulfide in the sediments. 


\subsection{Modified Shoaling Model on the G-LB Records}

Zhang et al. [69] first analyzed the multiple sulfur isotopes in the G-LB sediments. They reported the quadruple sulfur isotopic composition of pyrite in G-LB carbonates at Penglaitan, the GSSP for the G-LB, and Tieqiao in Laibin, Guangxi, South China, and at the EF section in west Texas, U.S. (Figure 1b). The analyzed 13-m-thick G-LB interval at Penglaitan accumulated in the Dian-Qian-Gui Basin, a southern extension of the Jiangnan Basin, in southern South China, and is composed of lower 9-m-thick bioclastic limestones and upper 4-m-thick cherty limestones (Figure 3) [70-72]. The lower limestones are the Laibin Limestone, the uppermost part of the $\sim 250-\mathrm{m}$-thick Maokou Formation, and represent the lowstand systems tract accumulated in an upper slope setting [73]. Especially, the upper $\sim 4$-m-thick part of the Laibin Limestone is characterized by carbonate debris flow deposits with abundant crinoids. Pyrite framboid data suggest that the Laibin Limestone was generally deposited under oxic conditions [74], and this is supported by the occurrence of burrows in the limestones [71]. The contact between the Laibin Limestone and the overlying cherty limestones represents a major flooding surface. The overlying cherty limestones of deep-water facies are the basal part of the Lopingian Heshan Formation, accumulated in a deep-water basin [73]. Pyrite framboid data suggest their deposition under dysoxic conditions [75] with intermittent euxinia [74]. The G-LB is assigned in the uppermost part of the Laibin Limestone (the base of Bed 6k) based on the FAD of conodont Clarkina postbitteri postbitteri (Figure 3) [71].

The extinction horizons in the G-LB interval at Penglaitan are controversial (Figure 3). An ammonoid turnover occurs in the uppermost part of the Laibin Limestone immediately above the G-LB ([76]; cf., [77]). Kaiho et al. [78] suggested the abrupt extinction at the bottom of the Lopingian Heshan Formation, based on the lithofacies and carbon isotopic analyses. A turnover in conodont fauna from a Guadalupian genus Jinogondolella to a Lopingian Clarkina is recorded immediately below the G-LB [71]. The major extinction of Guadalupian large fusulinids occurred in the uppermost part of the Laibin Limestone (immediately below the G-LB) in the J. granti Zone in the latest Capitanian (Late Guadalupian) [71,79]. Huang et al. [80] reported the earlier demise of a metazoan reef system with the extinction of corals and alatoconchid bivalves at the top of Bed 4 in the J. granti Zone. Shen and Shi [79] reported the occurrence of brachiopods of Lopingian aspect in the lower part of the Laibin Limestone (Beds $2 c$ and $3 b$ ), and suggested that the pre-Lopingian biotic crisis occurred in the J. xuanhanensis Zone in the late Capitanian. In addition, Wignall et al. [75] attributed the absence of large and complex fusulinaceans in the analyzed Laibin Limestone to their extinction significantly before the G-LB. Hence, although details are still unknown, the extinction may have occurred in three steps in the Laibin Limestone at Penglaitan $[79,80]$. It is uncertain whether this apparently stepwise extinction pattern at Penglaitan reflected the global extinction possibly occurred gradually in the Capitanian [81-83], or a local facies control. Arefifard and Payne [84] noted an effect of local facies control on the disappearance pattern of fusulinids in Capitanian successions on a global scale, and suggested the single and rapid extinction of large fusulinids in the latest Capitanian. On the other hand, Bond et al. $[85,86]$ pointed out that the major extinction event occurred in the mid-Capitanian, significantly before the G-LB (cf., [87]). The timing and pattern of the end-Guadalupian (or "Capitanian") extinction should be better constrained by further works.

Zhang et al. [69] reported that the $\delta^{34} S$ values of sedimentary pyrite ranged mostly from $-20 \%$ to $0 \%$ through the analyzed interval (Figure 3), although the values dropped sharply at the G-LB to ca. $-50 \%$. The negative $\Delta^{33} \mathrm{~S}$ values were observed throughout the interval. 


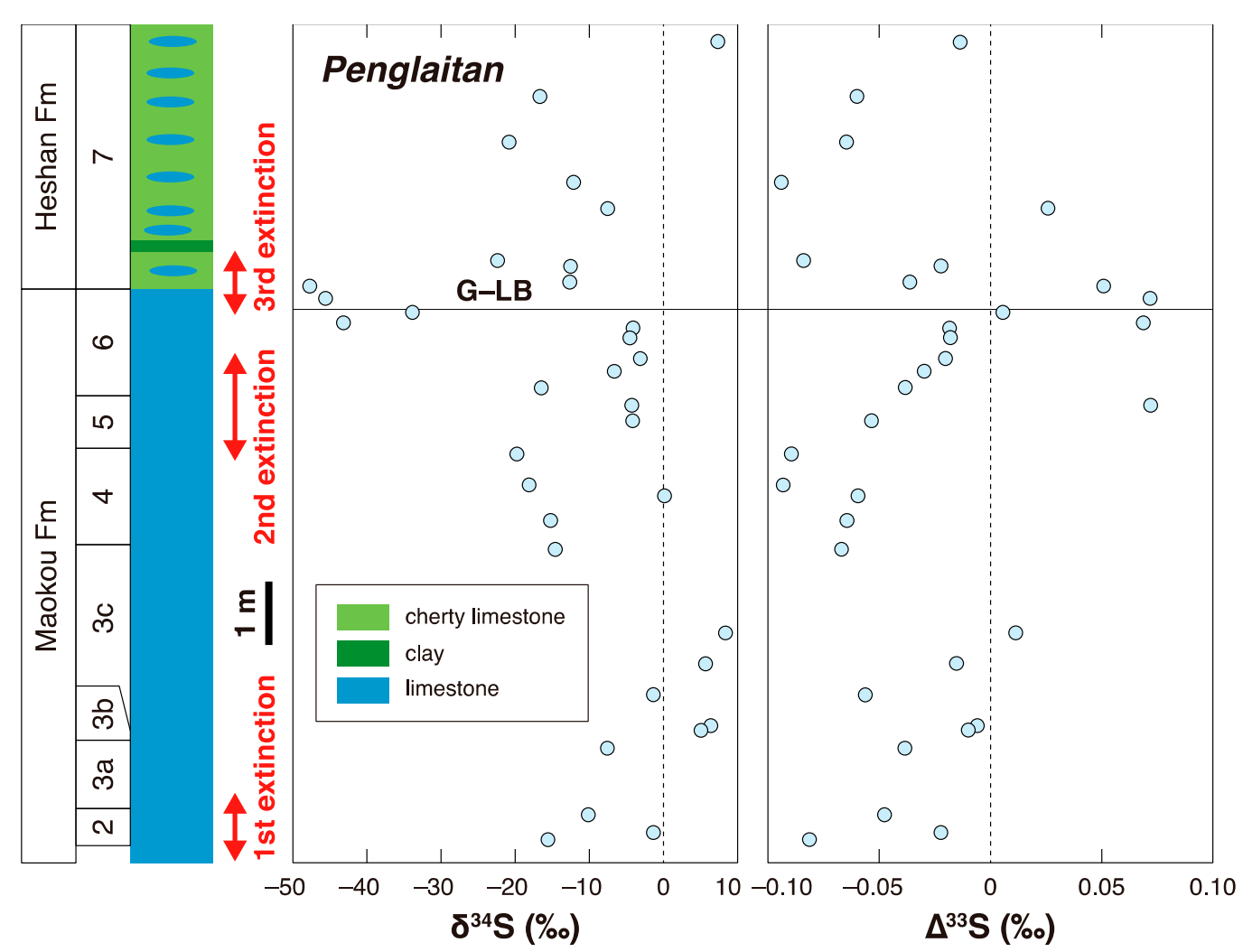

Figure 3. Multiple sulfur isotope chemostratigraphy across the Guadalupian-Lopingian boundary (G-LB) at Penglai$\tan$ [69]. A number along the log is Bed number. The estimated three extinction intervals are after Shen and Shi [79] and Huang et al. [80].

The Tieqiao section is located $\sim 10 \mathrm{~km}$ west of the Penglaitan section and has been regarded as a supplementary reference section of the GSSP for the G-LB [71]. The lithoand bio-stratigraphy of the analyzed $\sim 17.5$-m-thick G-LB interval at Tieqiao is similar to that at Penglaitan (Figure 4). The G-LB interval consists of the lower 10.5-m-thick Laibin Limestone and upper $\sim 7-\mathrm{m}$-thick cherty limestones of the Heshan Formation [70-72]. The Laibin Limestone is gray bioclastic limestones accumulated in an upper slope setting [73]. The similarity of lithofacies of the Laibin Limestone between Tieqiao and Penglaitan may suggest that the limestones were generally deposited under oxic conditions [74], although pyrite framboid data suggest that its uppermost part was deposited under dysoxic conditions [75]. The overlying cherty limestones of the Heshan Formation accumulated in a deep-water basin [73], under dysoxic/anoxic (or possibly euxinic) conditions [18,75].

At Tieqiao, the G-LB is assigned in the uppermost part of the Laibin Limestone based on the FAD of $C$. postbitteri (Figure 4) [71,72,88], although the extinction horizon in the analyzed G-LB interval has not been well constrained. Chen et al. [89] described a skeletal mound in the Laibin Limestone at Tieqiao, possibly correlated to a metazoan reef in the Laibin Limestone at Penglaitan [80], and reconstructed sea-level changes in the G-LB interval. Based on the results, they suggested that the potential extinction horizon was in the uppermost part of the Laibin Limestone, $\sim 30 \mathrm{~cm}$ above the G-LB. In contrast, together with the observations at Penglaitan, Wignall et al. [75] proposed that the extinction of large fusulinaceans occurred by the J. granti Zone, significantly before the G-LB, as mentioned above. Zhang et al. [90] reported a sharp decline in diversity and abundance of smaller foraminifers at the top of the Laibin Limestone at Tieqiao. However, this apparent disappearance of smaller foraminifers immediately above the G-LB was largely due to a facies control according to the deepening in the earliest Lopingian, rather than the global extinction. This is because most genera of smaller foraminifers observed in the Guadalupian Maokou Formation reappear in the middle to upper part of the overlying Heshan Formation. They concluded that the magnitude of the extinction 
of smaller foraminifers across the G-LB was not significant [90]. Based on the updated conodont zonation at Tieqiao, Sun et al. [88] also suggested that conodonts did not suffer substantial losses during the Capitanian. As in the case of Penglaitan, the timing and pattern of the extinction in the G-LB interval at Tieqiao should be better constrained in the future.

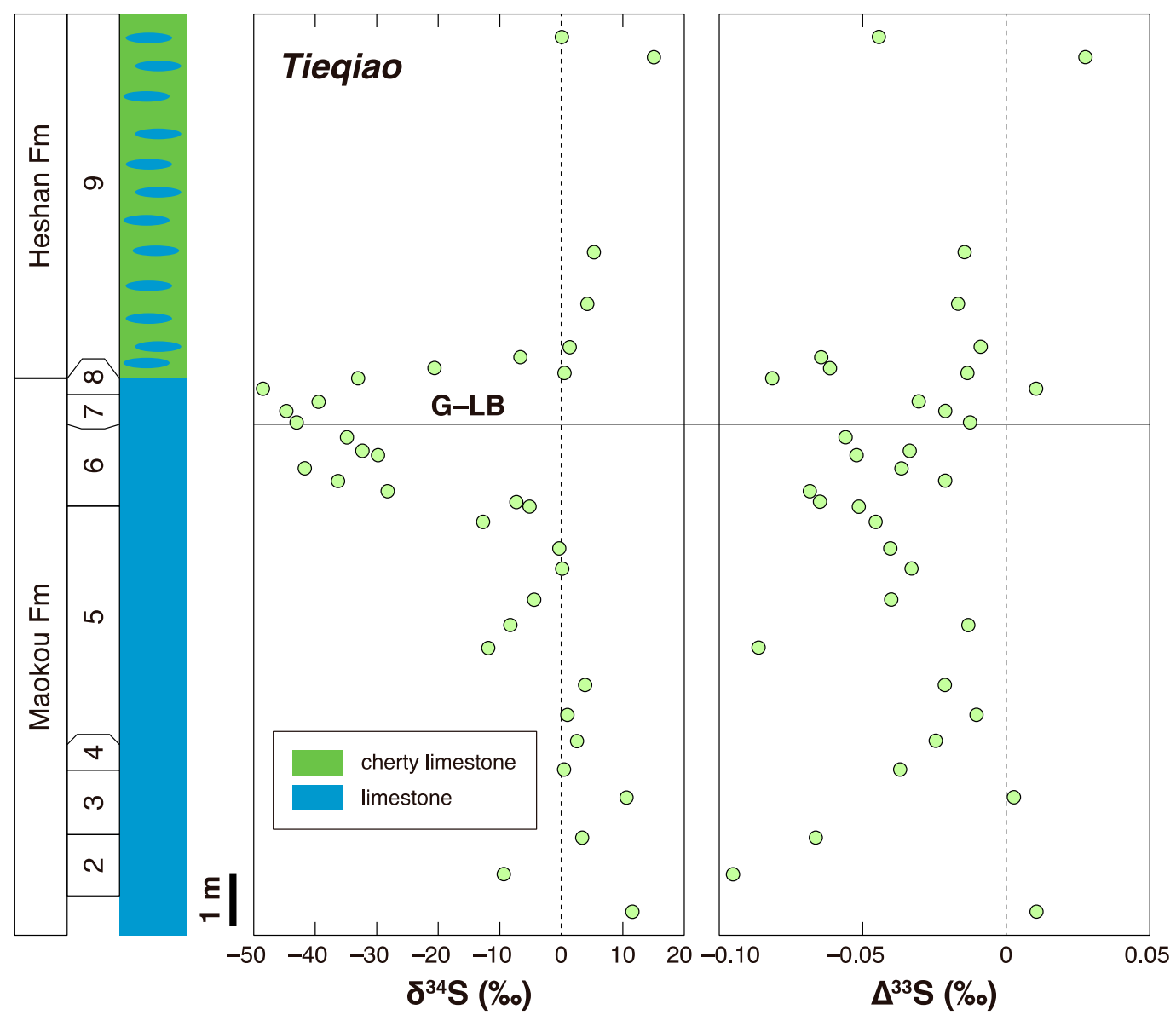

Figure 4. Multiple sulfur isotope chemostratigraphy across the G-LB at Tieqiao [69]. A number along the log is bed number. The timing and pattern of the extinction in the interval have not been well constrained.

Zhang et al. [69] reported that the $\delta^{34} S$ values of pyrite ranged mostly from $-10 \%$ to $+10 \%$ in the analyzed interval (Figure 4 ). However, the $\delta^{34} S$ values dropped sharply around the G-LB to ca. $-50 \%$, and this negative $\delta^{34} S$ excursion was correlated with that at Penglaitan (Figure 3), and also with that of carbonate-associated sulfate around the G-LB at Tieqiao [18]. The negative $\Delta^{33} S$ values are observed through the interval.

At the EF section in west Texas (Figure 1b), the uppermost part of the Guadalupian Bell Canyon Formation is overlain by the Lopingian Castile Formation (Figure 5) [91]. The analyzed interval accumulated in the Apache Mountains along the southwestern flank of the Delaware Basin in western Pangea. The siliciclastic Bell Canyon Formation accumulated in a forereef slope setting with calcareous gravity-flow deposits and allochthonous reefal debris, which were derived from the coeval Capitan Limestone of reefal facies on a shallower shelf margin [92]. In contrast, the overlying evaporitic Castile Formation extensively accumulated in the Delaware Basin after a substantial shallowing around the G-LB, which was associated with a large eustatic regression $[7,93,94]$.

The analyzed $\sim 11-\mathrm{m}$-thick interval at EF is composed mainly of bedded carbonates and is subdivided into five sedimentary units, Units A to E, in ascending order (Figure 5) $[91,92,95]$. The $\sim 3.3-\mathrm{m}$-thick basal Unit A is composed of skeletal carbonate mudstone to wackestone. The overlying 1.7-m-thick Unit B ("the first siltstone unit" 
in Wardlaw and Nestell [91]) is composed of thinly interbedded skeletal carbonate and calcareous siltstone. The $\sim 3.7-\mathrm{m}$-thick Unit C consists of bedded wackestone to carbonate mudstone. The $1.2-\mathrm{m}$-thick Unit D ("the second siltstone unit" in Wardlaw and Nestell [91]) is composed of interbedded skeletal carbonate and calcareous siltstone. The 1.0-m-thick uppermost Unit E consists of the lower $~ 0.3-\mathrm{m}$-thick skeletal limestones (Bed E1 and E2), and the upper 0.6-m-thick dolomitic and gypsiferous limestones (Bed E3-E5). The E2-E3 boundary in the Unit E is the boundary between the Bell Canyon and Castile formations [91,92]: the lower E1 and E2 are the uppermost part of the Bell Canyon Formation, whereas the upper E3-E5 are the basal part of the Castile Formation. Lambert et al. [96] reported the occurrence of conodont C. hongshuiensis in Bed E1 (Figure 5), which characterizes the latest Capitanian [97], although the G-LB has not been precisely assigned at EF.

$\mathrm{Wu}$ et al. [98] reported high-precision $\mathrm{U}-\mathrm{Pb}$ geochronology of zircons from ash beds of the Belle Canyon Formation in the Guadalupe Mountains along the northwestern flank of the Delaware Basin. Based on the results, they suggested that the end-Guadalupian extinction occurred within the last 1 million years of the Capitanian and in the earliest Lopingian. Smith et al. [99] conducted multiple geochemical analyses of shallow- and deep-water carbonates from the Guadalupe and Apache Mountains. They proposed that the restricted geometry of the Delaware Basin stimulated drastic changes in water chemistry during a sea-level fall in the Capitanian, such as elevated salinity, water-column stratification, and bottom water anoxia, leading to the severe and physiologically selective extinction in the isolated basin. Shen et al. [94] correlated the entire Guadalupian series in the Guadalupe Mountains to that in South China. In the framework of composite bio- and chemo-stratigraphy and geochronology, they concluded that the fossil records of the uppermost Capitanian rocks in the Guadalupe Mountains were truncated by the abrupt lithofacies change from the marine successions to the Castile evaporites. At the EF section in the Apache Mountains, the analyzed interval of the uppermost part of the Bell Canyon Formation accumulated in the early to latest Capitanian on the basis of conodont zonation [91,96]. In particular, the latest Capitanian strata are exceptionally preserved in its uppermost part (Figure 5). Nevertheless, the timing and pattern of the extinction in the analyzed interval have been poorly constrained.

Zhang et al. [69] reported that the $\delta^{34} S$ values increased from ca. $-30 \%$ o to $0 \%$ o upward (Figure 5), and then decreased to ca. $-35 \%$ in the uppermost part of the analyzed interval. In particular, the $\delta^{34} S$ decrease in the latest Capitanian could be correlated with the negative $\delta^{34} \mathrm{~S}$ excursion around the G-LB at Penglaitan and Tieqiao (Figures 3 and 4). The $\Delta^{33} S$ values are generally negative in the siltstone-bearing units $B$ and $D$.

Zhang G.J. et al. [69] detected the negative $\Delta^{33} S$ values in the analyzed intervals at Penglaitan, Tieqiao, and EF (Figure 6). For explaining the negative $\Delta^{33}$ S records, they slightly modified the shoaling model in Shen Y. et al. [55]. In the original shoaling model by Shen Y. et al., the negative $\Delta^{33} \mathrm{~S}$ signals indicate a mixing of ${ }^{34} \mathrm{~S}$-depleted and ${ }^{34} \mathrm{~S}$-enriched sulfur, and ${ }^{34} \mathrm{~S}$-depleted $\mathrm{H}_{2} \mathrm{~S}$ was produced via MSR in an open sediment with burrows under oxic conditions. In their revised model, Zhang G.J. et al. [69] interpreted that ${ }^{34}$ Sdepleted $\mathrm{H}_{2} \mathrm{~S}$ could also have been produced via MSR in the anoxic water column, which resulted in the emergence of a sulfidic (not anoxic) deep-water mass. ${ }^{34}$ S-depleted $\mathrm{H}_{2} \mathrm{~S}$ in the deep-water mass was then supplied to the shelf sediment via shoaling, and was mixed with ${ }^{34} \mathrm{~S}$-enriched $\mathrm{H}_{2} \mathrm{~S}$ produced via quantitative MSR in the shelf sediment according to the shutdown of bioturbation. Consequently, the bulk $\Delta^{33} S$ value of the sediment became negative. According to the revised shoaling model, Zhang G.J. et al. [69] concluded that shoaling of sulfidic deep-waters may have contributed to the end-Guadalupian extinction on a global scale. 


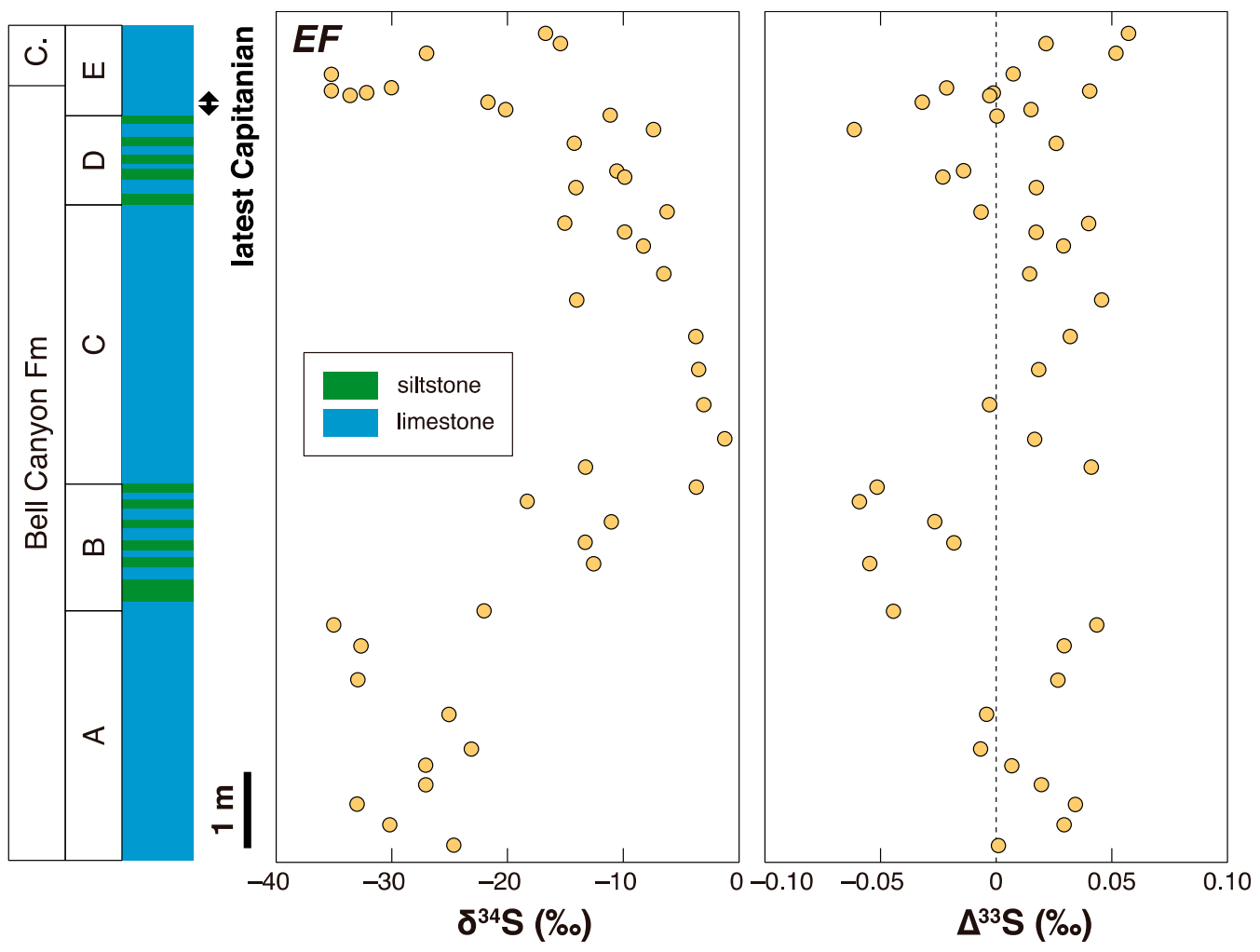

Figure 5. Multiple sulfur isotope chemostratigraphy across the G-LB at EF [69]. Alphabet along the log is Unit name. The latest Capitanian interval in the uppermost part of the Bell Canyon Formation is characterized by the occurrence of conodont Clarkina hongshuiensis [96]. C.: Castile Fm.

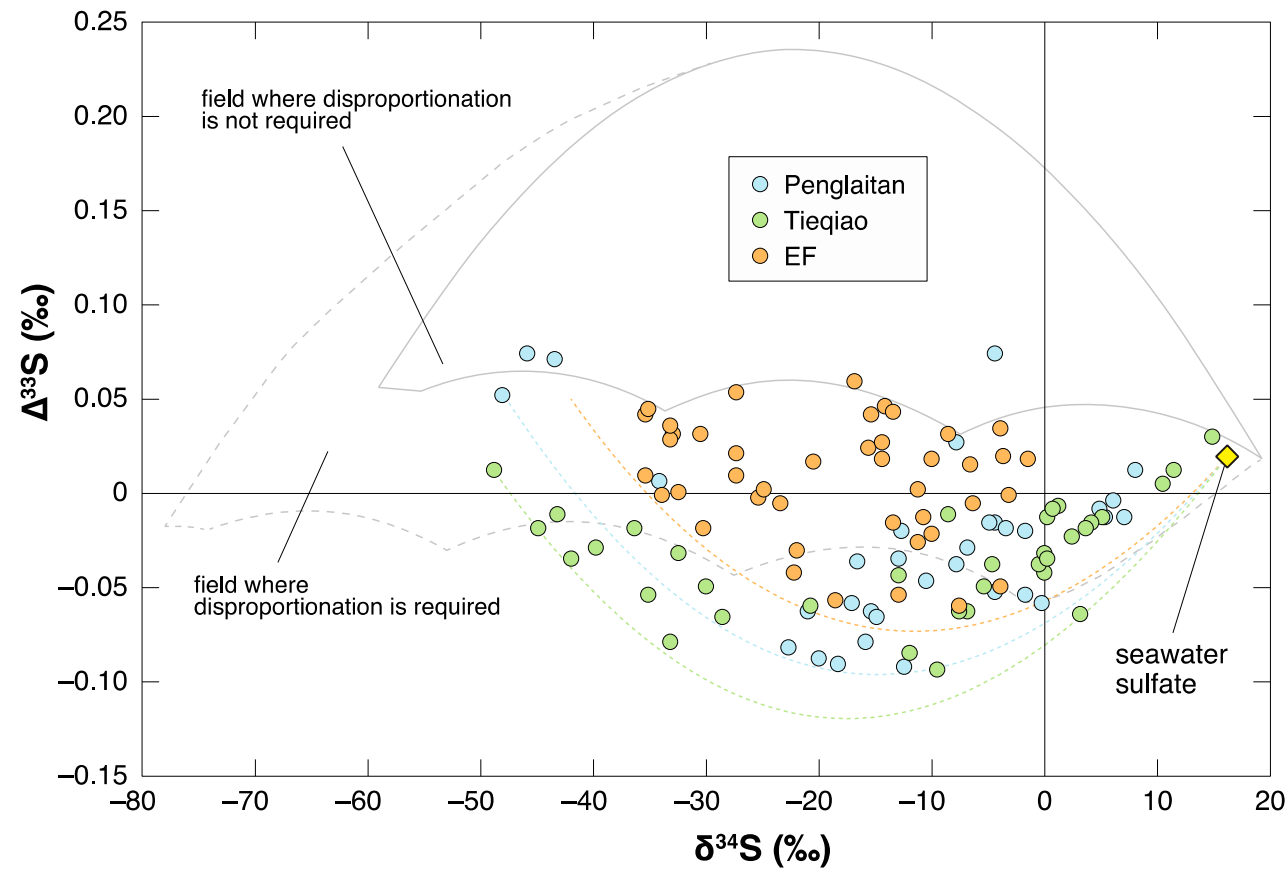

Figure 6. $\delta^{34} \mathrm{~S}-\Delta^{33} \mathrm{~S}$ cross plot at Penglaitan, Tieqiao, and EF [69]. The estimated $\delta^{34} \mathrm{~S}$ and $\Delta^{33} \mathrm{~S}$ values of contemporaneous seawater sulfate $(+16.2 \%$ and $+0.020 \%$, respectively) are from Wu et al. [68]. A convex downward curve is a possible mixing trend for each section. 


\section{Later Multiple Sulfur Isotope Studies in the Permian-Triassic Transition Interval}

Following Shen Y. et al. [55] and Zhang G.J. et al. [69], several studies reported the multiple sulfur isotope records during the Permian-Triassic transition, particularly focusing on the three extinction events (Figure 1a).

\section{1. $G-L B$}

To test the shoaling model in Zhang G.J. et al. [69], Saitoh et al. [100] analyzed the multiple sulfur isotopes in sedimentary pyrite from the G-LB interval at Chaotian, South China (Figure 1b), focusing on the benthic redox conditions in the depositional settings. At Chaotian along the northwestern edge of South China, carbonates and terrigenous clastics of relatively deep-water facies accumulated on a slope/basin setting during the Permian to earliest Triassic [16]. The G-LB interval is composed of $~ 25-\mathrm{m}$-thick bioclastic Maokou limestone (Limestone Unit), 11-m-thick thinly bedded black mudstone/chert (Mudstone Unit), a 3-m-thick felsic Wangpo tuff bed, and 20-m-thick bioclastic Wujiaping limestone, in ascending order (Figure 7a). Based on the litho- and bio-facies, the Maokou and Wujiaping limestones accumulated on a shallow oxic shelf with common burrows, whereas the Mudstone Unit accumulated on a relatively deep disphotic slope/basin under sulfidic conditions $[16,101]$. The Limestone Unit and the $\sim 8-\mathrm{m}$-thick lower part of the overlying Mudstone Unit accumulated in the early Capitanian based on the occurrence of J. postserrata and J. shannoni $[16,102,103]$. The $\sim 3$-m-thick upper part of the Mudstone Unit possibly accumulated in the middle Capitanian although no conodont occurs in this part. The upper Capitanian rocks are possibly missing at Chaotian due to an abrupt shallowing around the G-LB $[16,102]$. The extinction horizon is tentatively assigned at the top of the Mudstone Unit. The G-LB is assigned at the bottom of the Wujiaping limestone based on the abundant occurrence of small fusulines, Codonofusiella and Reichelina.

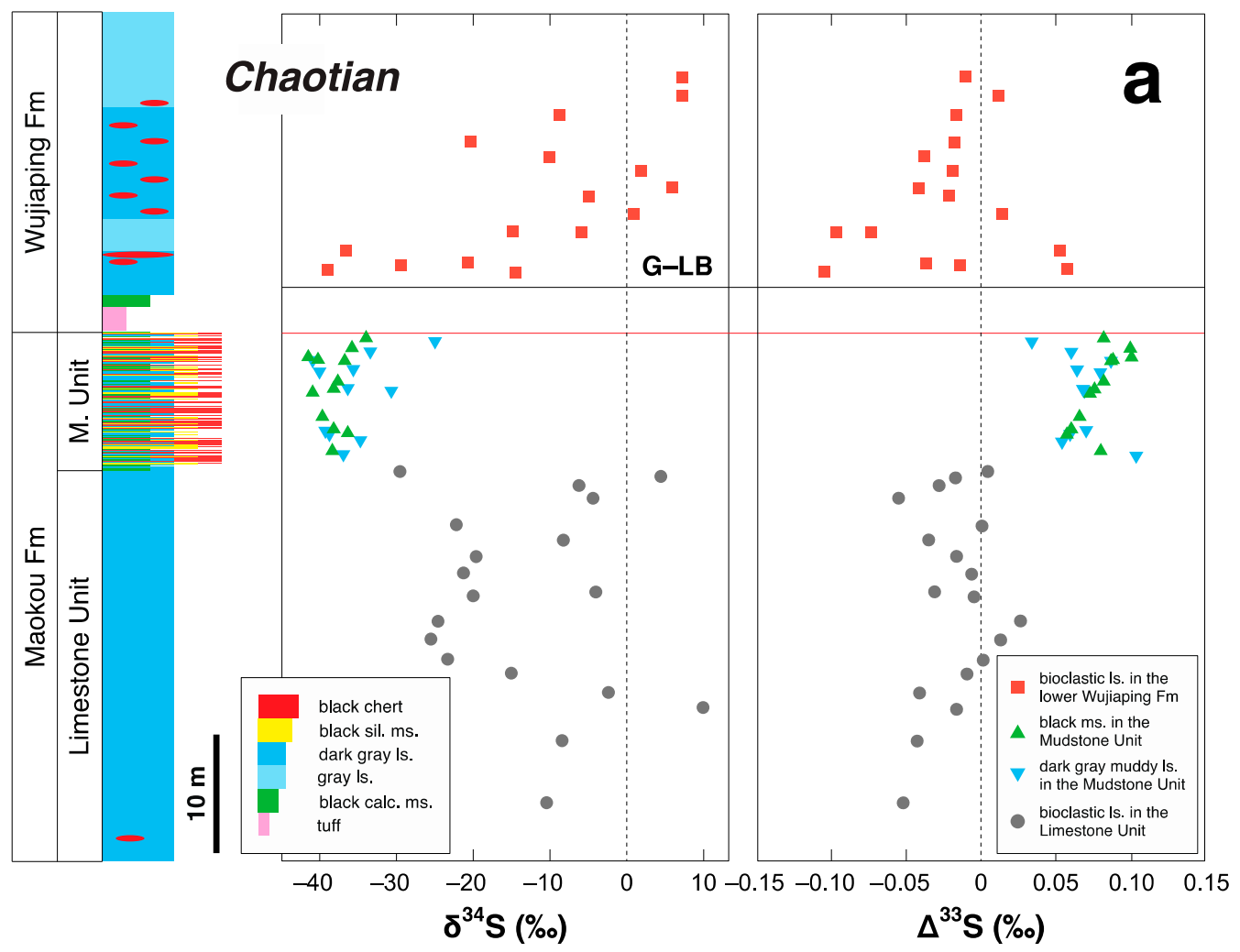

Figure 7. Cont. 


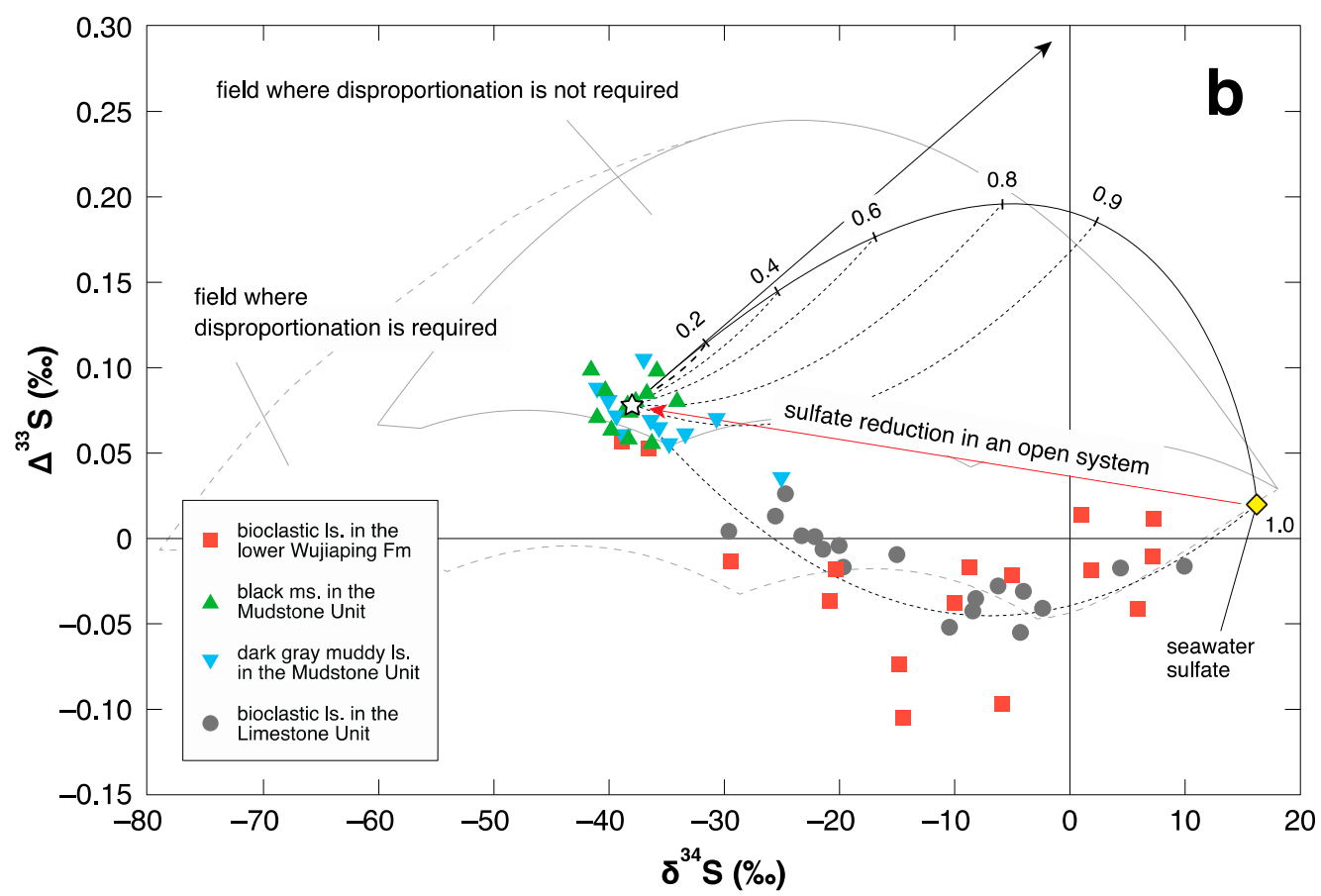

Figure 7. Multiple sulfur isotope record across the G-LB at Chaotian [100]. (a) sulfur isotope chemostratigraphy. A red line represents the estimated extinction horizon. M. Unit: Mudstone Unit, sil.: siliceous, calc.: calcareous, ms.: mudstone, ls.: limestone; (b) $\delta^{34} \mathrm{~S}-\Delta^{33} \mathrm{~S}$ cross plot. A star represents the average black mudstone. The solid black arrow and curve represent the evolution of instantaneously produced $\mathrm{H}_{2} \mathrm{~S}$ and accumulatively produced $\mathrm{H}_{2} \mathrm{~S}$, respectively, via reduction of the contemporaneous seawater sulfate [68] in a closed system, assuming that the ${ }^{34} \varepsilon$ and ${ }^{33} \lambda$ values in MSR were $53.5 \%$ and 0.514 (red arrow), respectively. A number on the curve is a fraction of sulfate converted to $\mathrm{H}_{2} \mathrm{~S}$. A black dashed curve shows a mixing of accumulative $\mathrm{H}_{2} \mathrm{~S}$ and sulfide produced in an open system (star). Note that the oxic limestones record the negative $\Delta^{33} \mathrm{~S}$ signals and are generally along the mixing curve between sulfide produced in an open system and sulfide produced via quantitative MSR in a closed system. Fields where disproportionation is required and not required are from Zhang G.J. et al. [69].

Saitoh et al. [100] showed that the Mudstone Unit was characterized by consistently low $\delta^{34} S\left(\right.$ mostly $<-30 \%$ ) and high $\Delta^{33} S$ (up to $+0.10 \%$ ) values (Figure 7 ). Those sulfur isotopic signals probably reflected the enhanced water-mass sulfate reduction in the anoxic water column, which resulted in the emergence of a sulfidic deep-water mass on the relatively deep slope/basin. This interpretation is consistent with the petrological and geochemical observations of the Mudstone Unit (e.g., the abundant occurrence of smallsized pyrite framboids). Saitoh et al. [100] suggested that the sulfidic deep-water mass may have contributed to the extinction on the shallow shelf via shoaling, and this scenario was apparently consistent with the shoaling model in Zhang G.J. et al. [69]. However, a shelf record during the extinction event is missing at Chaotian due to a local subsidence of the sedimentary basin and to a G-LB unconformity $[16,102]$. It was therefore difficult to test the Zhang G.J. et al.'s shoaling model by examining the redox and $\Delta^{33} \mathrm{~S}$ record of the shelf sediment during the extinction at Chaotian.

Interestingly, Saitoh et al. [100] found negative $\Delta^{33} \mathrm{~S}$ signals in the Maokou and Wujiaping limestones (Figure 7). These bioclastic limestones accumulated on the oxic shelf with common burrows [16,101]. According to the shoaling model in Zhang G.J. et al. [69], the negative $\Delta^{33} S$ value of the sediment was a result of mixing of ${ }^{34} S$-depleted and ${ }^{34} S$-enriched sulfide in a sediment via shoaling of sulfidic deep-water. Thus, this anomalous isotopic signal should have been limited to euxinic sediments. The commonly observed negative $\Delta^{33} \mathrm{~S}$ signals in the oxic limestones at Chaotian are apparently inconsistent with the previous shoaling model. To explain the isotope records, Saitoh et al. [100] modified the sulfur mixing model in Zhang G.J. et al. [69]. They interpreted that the negative $\Delta^{33}$ S signals 
in the shelf limestones were owing to local sulfur isotope heterogeneity in the sediments. According to their revised sulfur mixing model, both of the ${ }^{34}$ S-depleted and ${ }^{34} S$-enriched sulfides were produced in the oxic sediments. ${ }^{34}$ S-depleted sulfide was produced via MSR within the burrows, which were connected to the sulfate-enriched water column and were a local open system in the sediments. On the other hand, ${ }^{34}$ S-enriched sulfide was produced via quantitative MSR in a local closed system within the sediments. The bulk $\Delta^{33} S$ value of the sediments became negative by their mixing. As described in Section 2.2, Shen Y. et al. [55] assumed that an oxic sediment was a fully open system with respect to sulfate due to enhanced benthos activity. However, the observed negative $\Delta^{33} \mathrm{~S}$ signals in the shelf limestones at Chaotian suggested that ${ }^{34} \mathrm{~S}$-depleted and ${ }^{34} \mathrm{~S}$-enriched sulfides coexisted in the local oxic sediments, even when the sediments were well bioturbated. The Chaotian data also suggested that the sulfur isotopic composition of pyrite was spatially heterogenous in the sediments at the hand-specimen scale.

\section{2. $P-T B$}

Zhang et al. [67] analyzed the multiple sulfur isotopic composition of sedimentary pyrite across the P-TB at Opal Creek in British Columbia, western Canada, and at GujoHachiman in central Japan (Figure 1b). At Opal Creek, the >20-m-thick Phroso Siltstone Member of the Sulphur Mountain Formation is composed mainly of black to dark gray shale and siltstone, accumulated on an outer shelf or slope in the Lopingian to Early Triassic (Figure 8a) [104]. In the siliciclastic succession, the main extinction horizon $\sim 0.4 \mathrm{~m}$ above the basal unconformity is characterized by a turnover in conodont fauna and the disappearance of bioturbation. The P-TB is assigned at the horizon $\sim 1 \mathrm{~m}$ above the extinction horizon in the shale, based on the FAD of H. parous (Figure 8a) [105]. Schoepfer et al. [104] suggested that the basal $\sim 4$-m-thick shale/siltstone, including the extinction horizon and P-TB, were deposited under sulfidic conditions, whereas the overlying $>15$-m-thick siltstone-dominant part accumulated under oxic to suboxic conditions, on the basis of pyrite framboid and multiple geochemical data.

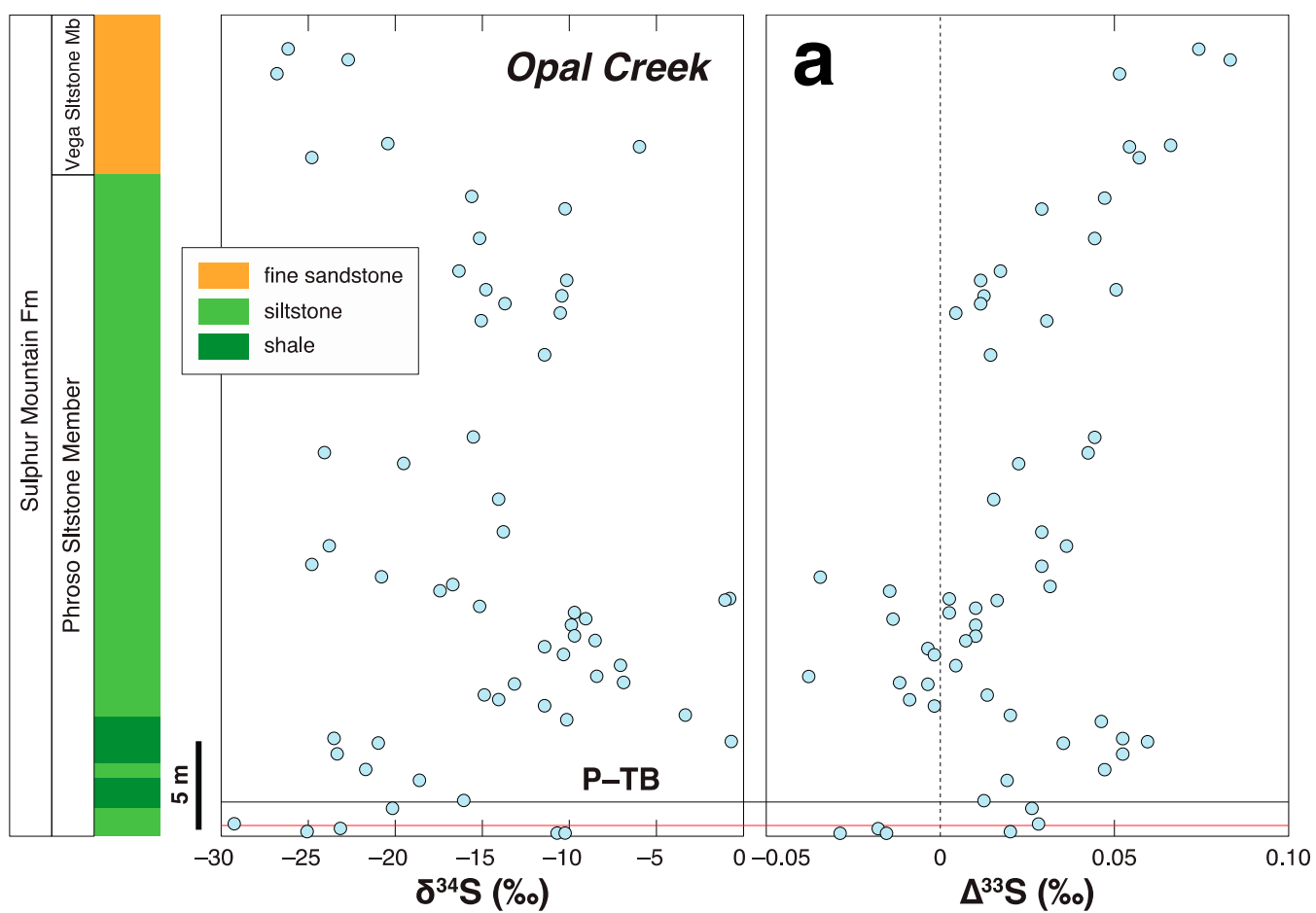

Figure 8. Cont. 


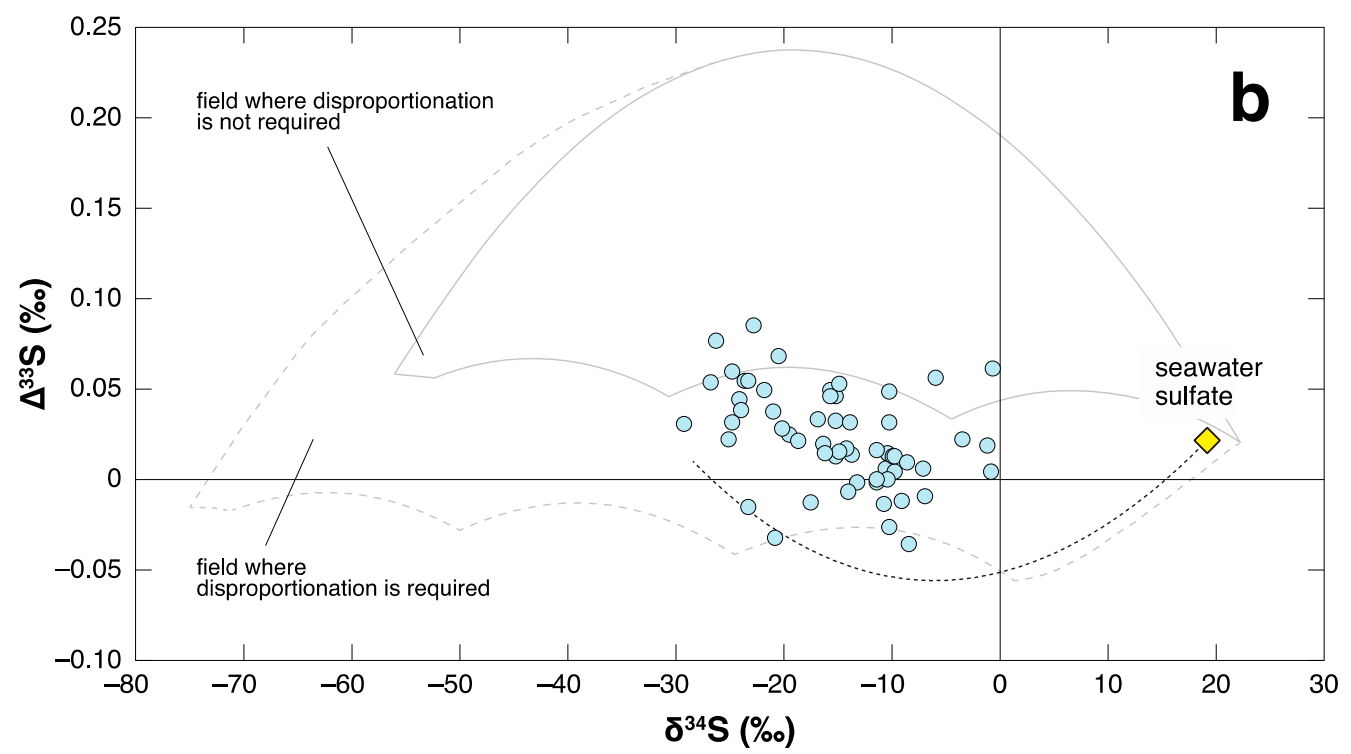

Figure 8. Multiple sulfur isotope record across the P-TB at Opal Creek [67]. (a) sulfur isotope chemostratigraphy. A red line represents the extinction horizon [105]; (b) $\delta^{34} S-\Delta^{33} S$ cross plot. The estimated $\delta^{34} S$ and $\Delta^{33} S$ values of contemporaneous seawater sulfate are from $\mathrm{Wu}$ et al. [68]. A possible mixing curve is after Zhang et al. [67].

Zhang et al. [67] found negative $\Delta^{33} S$ values in the basal siltstone immediately below the extinction horizon (Figure 8a), and attributed them to shoaling of sulfidic deep-water following the Shen Y. et al.'s model [55]. In contrast to the negative $\Delta^{33} \mathrm{~S}$ values of the basal siltstone, the value of the overlying shale across the P-TB is consistently positive, up to $+0.06 \%$, with relatively low $\delta^{34} \mathrm{~S}$ values (mostly $<-20 \%$ ). Zhang et al. [67] interpreted that those sulfur isotopic signals showed an increased influx of syngenetic pyrite with positive $\Delta^{33} S$ and negative $\delta^{34} S$ into the sediments under sustained euxinic conditions. Their interpretation is consistent, at least in part, with the Schoepfer et al. [104]'s observation that the basal 4-m-thick shales/siltstones accumulated under sulfidic conditions.

The negative $\Delta^{33} S$ values reappear in the lower part of the overlying siltstone (Figure 8a). Zhang et al. [67] inferred episodic shoaling of sulfidic water and oscillations between sulfidic and oxic conditions in the depositional setting during the deposition of the part. This scenario is apparently inconsistent with the previous suggestion that the siltstone was deposited predominantly under oxic to suboxic conditions [104]. The shoaling inflow of sulfidic deepwater was substantially reduced and the sulfidic deep-water may have shoaled intermittently during the siltstone deposition (cf., [106]). The substantial decline in inflow of sulfidic water with ${ }^{33} \mathrm{~S}$-enriched $\mathrm{H}_{2} \mathrm{~S}$ may have been responsible for the observed $\Delta^{33} \mathrm{~S}$ decrease, from the positive values of the P-TB shale to the negative values of the overlying siltstone. The supposed decline in shoaling inflow of sulfidic deep-water is consistent with the cessation of coastal upwelling during the siltstone deposition [104]. The $\Delta^{33} S$ values increase to be positive in the upper part of the siltstone, though its cause is uncertain. Zhang et al. [67] concluded that the multiple sulfur isotope record at Opal Creek was generally consistent with the shoaling scenario in Shen Y. et al. [55] at Meishan, and implied that episodic shoaling of sulfidic deep-water occurred on a global scale at the end-Permian.

At Gujo-Hachiman in central Japan, bedded cherts and siliceous claystones occur as an allochthonous block in a Jurassic accretionary complex in the Mino-Tanba belt. The Gujo-Hachiman succession accumulated originally in an abyssal setting on the deep-ocean floor in mid-Panthalassa in the Guadalupian to possibly earliest Triassic (Figure 1b) (e.g., $[107,108])$. The analyzed $~ 4-m$-thick P-TB interval at Gujo-Hachiman consists of $\sim 3.2$-m-thick gray chert (unit I), $\sim 0.2$-m-thick gray siliceous claystone (unit II), and $\sim 0.7$-m-thick black siliceous claystone (unit III), in ascending order (Figure 9a) [107,109]. The lower cherts (unit I) and the overlying gray siliceous claystones (unit II) are dated to Changhsingian (Late Lopingian) based on the occurrence of radiolarians such as Neoalbail- 
lella optima and Albaillella triangularis [109-111]. The Changhsingian age of the unit I cherts is supported by conodont zonation [111]. The unit II is overlain by the black siliceous claystones. The accumulation of black siliceous claystone around the P-TB is commonly observed in mid-Panthalassan deep-sea sequences in Japan, and has been thought to be a result of the demise of radiolarians and the decline in biogenic silica production during the global extinction $[5,112,113]$. Based on regional correlations, the extinction horizon at Gujo-Hachiman could be placed at the base of the black siliceous claystones (unit III) (Figure 9a).

The black siliceous claystones (unit III) yield no radiolarians or conodonts, except for the occurrence of radiolarians in siliceous claystone lenses/layers in the lower part, i.e., Albaillella triangularis and Neoalbaillella sp. $10 \mathrm{~cm}$ above the unit base, and Neoalbaillella $\mathrm{sp} .30 \mathrm{~cm}$ above the base [109]. The occurrence of Changhsingian radiolarians above the estimated extinction horizon has been problematic [107], though their absence in the matrix of the black claystones suggests that it was due to reworking of the fossils into the younger sediments [114] or their survival in the aftermath of the global mass extinction [115]. The assignment of the P-TB at Gujo-Hachiman is also uncertain due to the poor occurrence of index fossils $[107,116]$. At Ubara in the Kyoto Prefecture, located $160 \mathrm{~km}$ southwest of Gujo-Hachiman, a P-TB interval of similar lithological units (i.e., bedded gray cherts, gray siliceous claystones, and black siliceous claystones, in ascending order) is exposed as another deep-sea sediment block in the Mino-Tanba Belt, and H. parvus has been identified $10 \mathrm{~cm}$ above the base of the black siliceous claystones [117]. Based on this observation, Algeo et al. [107] placed the P-TB at Gujo-Hachiman tentatively near the base of the black siliceous claystones (unit III) (Figure 9a).

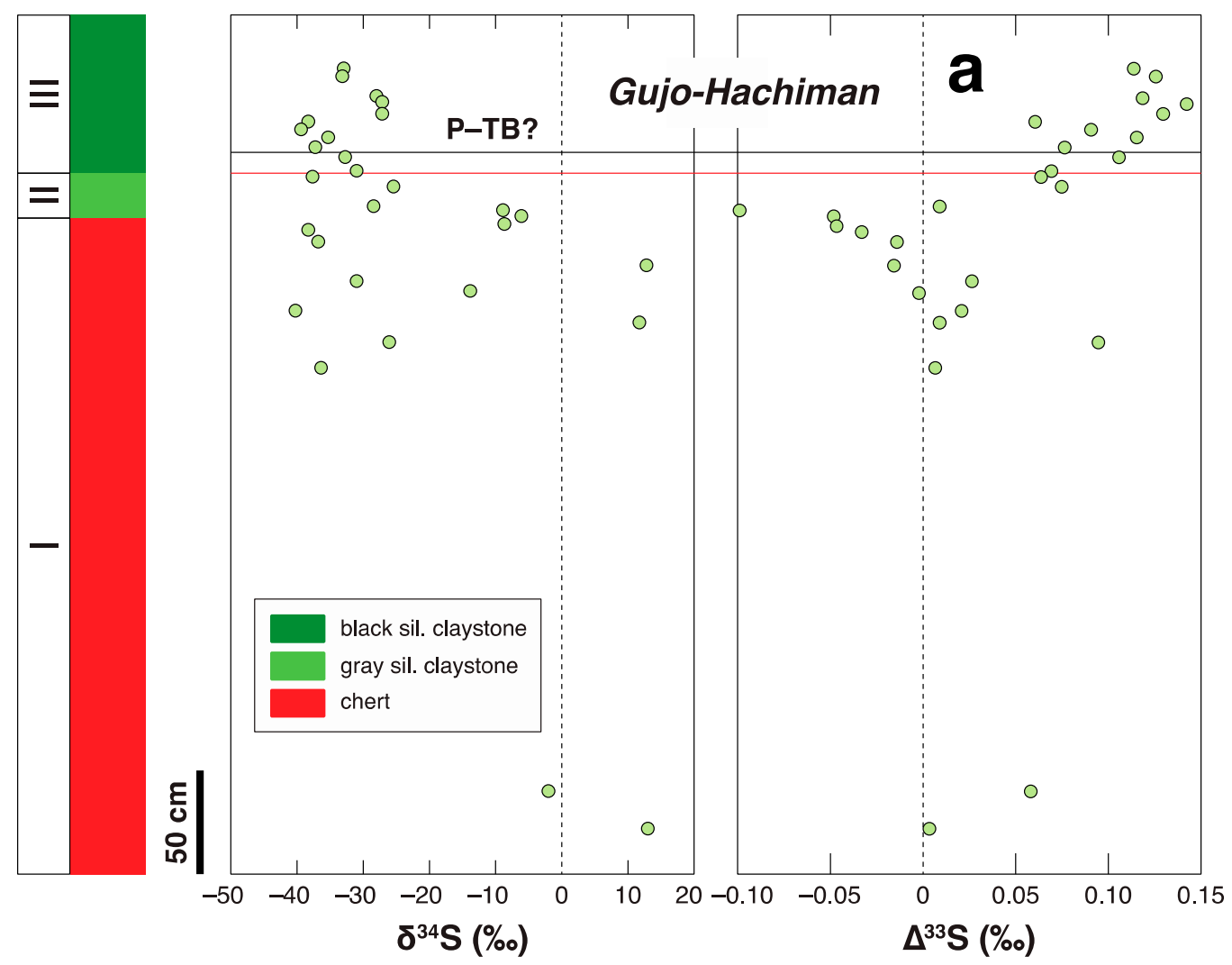

Figure 9. Cont. 


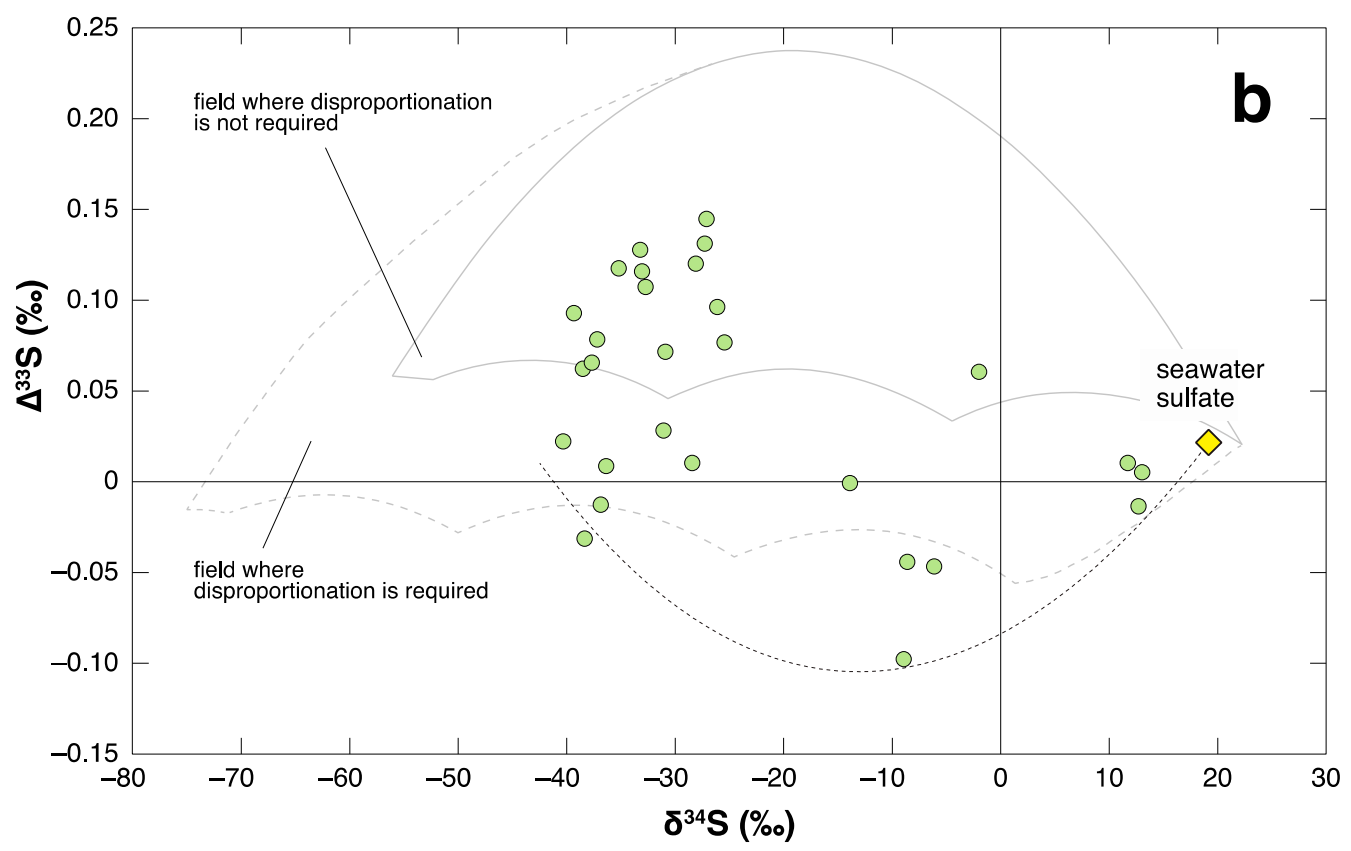

Figure 9. Multiple sulfur isotope record across the P-TB at Gujo-Hachiman [67]. (a) sulfur isotope chemostratigraphy. A red line represents the estimated extinction horizon. A Roman numeral along the log is unit name; (b) $\delta^{34} \mathrm{~S}-\Delta^{33} \mathrm{~S}$ cross plot. The estimated $\delta^{34} S$ and $\Delta^{33} S$ values of contemporaneous seawater sulfate are from Wu et al. [68]. A possible mixing curve is after Zhang et al. [67].

The deep-ocean redox conditions during the accumulation of the analyzed P-TB interval at Gujo-Hachiman have been controversial. Based on the composite stratigraphy of the abyssal sediments in Japan and in British Columbia, Canada, Isozaki $[5,118]$ proposed prolonged deep-ocean anoxia in Panthalassa during the Permian-Triassic transition interval (superanoxia). Although the long duration of superanoxia has been challenged by later studies (e.g., [119]), the deep-ocean anoxia/euxinia during the P-TB extinction event has been supported by petrological and geochemical observations on the abyssal sediments in Japan and New Zealand (e.g., [119-121]). Nevertheless, based on petrological and multiple geochemical analyses of the present Gujo-Hachiman succession, Algeo et al. [107] proposed that euxinic water masses developed within the oxygen-minimum zone while the bottom waters remained mostly suboxic through the P-TB interval.

Zhang et al. [67] analyzed pyrite in the Gujo-Hachiman sediments and found the negative $\Delta^{33} S$ values in the uppermost part of the gray cherts (unit I) and the overlying gray siliceous claystones (unit II) (Figure 9a). As the Gujo-Hachiman succession accumulated in the deep abyssal setting, shoaling of deep-water cannot be assumed for explaining the negative $\Delta^{33} \mathrm{~S}$ values. Zhang et al. interpreted that the negative $\Delta^{33} \mathrm{~S}$ signals recorded oscillations between sulfidic and oxic conditions in the deep ocean, and suggested that the supposed oscillations in deep oceanic redox in mid-Panthalassa in the Changhsingian were consistent with shoaling of sulfidic deep-water at Meishan in eastern Paleotethys and at Opal Creek in western Pangea around the P-TB (Figure 1b).

To re-examine the previous shoaling model, Saitoh et al. [122] recently analyzed the multiple sulfur isotopes in sedimentary pyrite across the P-TB at Chaotian (Figure 1b). The $\sim 40$-m-thick P-TB interval consists of $\sim 11$-m-thick bioclastic Wujiaping limestone, $\sim 25$-m-thick Dalong Formation of deep-water facies, a characteristic $~ 1.4$-m-thick marl unit, and $\sim 3.5-\mathrm{m}$-thick micritic Feixianguan limestone, in ascending order (Figure 10a). The major extinction horizon is at the bottom of the marl unit, and the P-TB is assigned at the bottom of the Feixianguan limestone on the basis of the FAD of $H$. parvus [123]. Based on the litho- and bio-facies, the Wujiaping limestone accumulated on a shallow oxic shelf, whereas the overlying thinly-bedded black siliceous/calcareous mudstones in the lower to middle part of the Dalong Formation were deposited on a relatively deep disphotic 
slope/basin under sulfidic conditions [124]. The depositional setting shifted to a shallower oxic slope in the upper part of the Dalong Formation. In the aftermath of the extinction, the marl unit and overlying Feixianguan limestone accumulated most likely on the slope under sulfidic conditions [122].

Saitoh et al. [122] showed that $\delta^{34} S$ and $\Delta^{33} S$ values are substantially low (mostly $<-35 \%$ ) and high (up to $+0.150 \%$ ), respectively, in the lower to middle part of the Dalong Formation (Figure 10). These isotopic signals indicated enhanced water-mass sulfate reduction and the emergence of a sulfidic deep-water mass on the deep slope/basin. The $\Delta^{33} \mathrm{~S}$ record of the analyzed P-TB interval at Chaotian was apparently inconsistent with the previous shoaling model in Shen Y. et al. [55] and Zhang et al. [67], for the following two reasons. Firstly, the negative $\Delta^{33} S$ values were observed in the oxic Wujiaping limestones with common burrows (Figure 10a). According to the previous shoaling model, the negative $\Delta^{33} S$ value should have been restricted to anoxic/sulfidic sediments, as mentioned in Section 3.1. Saitoh et al. [122] explained the negative $\Delta^{33} S$ data by the mixing of ${ }^{34} \mathrm{~S}$ depleted and ${ }^{34} \mathrm{~S}$-enriched sulfides produced in the oxic limestones, as in the case of the Maokou and Wujiaping limestones in the G-LB interval (Figure 7) [100]. Secondly, the $\Delta^{33} \mathrm{~S}$ values remained consistently positive across the extinction horizon, regardless of the sudden disappearance of bioturbation with the emergence of euxinia.

To better constrain the relationship between the sulfur isotope record and benthic redox conditions, Saitoh et al. [122] further examined a correlation between $\Delta^{33} S$ value and ichnofabric index of the P-TB sediments at Chaotian (Figure 11). According to the previous shoaling model, the negative $\Delta^{33} \mathrm{~S}$ value should have been restricted to anoxic/sulfidic sediments. Hence, if the shoaling model was correct, a positively correlated variation between the $\Delta^{33} S$ value and ichnofabric index would have been observed. However, the Chaotian data do not show such a variation. Saitoh et al. [122] expanded the previous shoaling model to resolve the apparent discrepancy between the sulfur isotope record at Chaotian and the model. When the deep-water was sulfidic and its shoaling rate was relatively high, a substantial amount of ${ }^{33} \mathrm{~S}$-enriched $\mathrm{H}_{2} \mathrm{~S}$ was supplied to a shelf sediment via shoaling, and the bulk $\Delta^{33} \mathrm{~S}$ value of the sediment became positive. This scenario was similar to that for the positive $\Delta^{33} \mathrm{~S}$ record of the euxinic P-TB shale at Opal Creek (Figure 8a) [67]. Saitoh et al. [122] further inferred that the observed variation in $\Delta^{33} \mathrm{~S}$ around the $\mathrm{P}-\mathrm{TB}$ on a global scale reflected a substantial variation in $\mathrm{H}_{2} \mathrm{~S}$ concentration and/or in upwelling rate of shoaled deep-waters. 

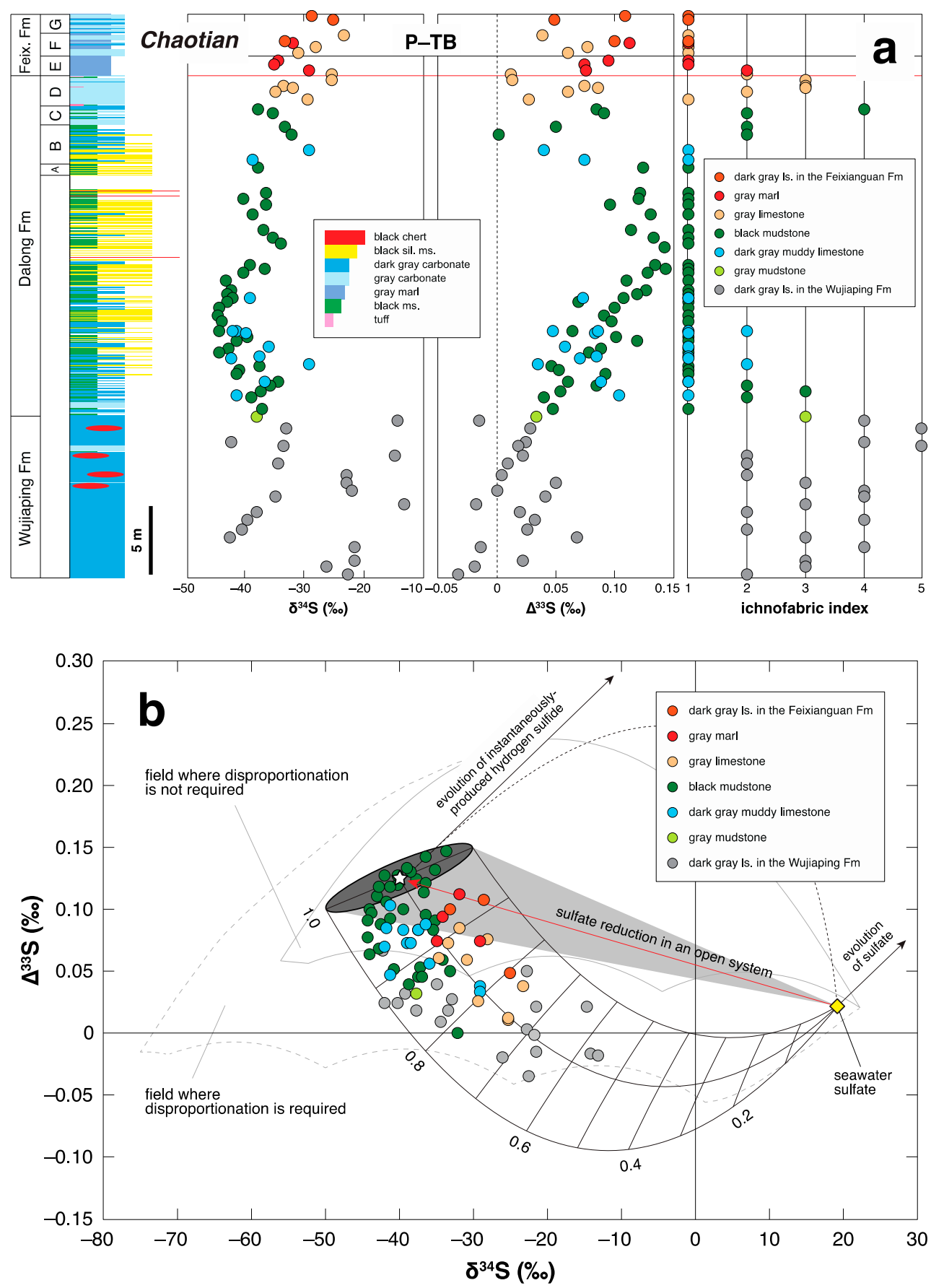

Figure 10. Multiple sulfur isotope record across the P-TB at Chaotian [122]. (a) sulfur isotope chemostratigraphy. A red line represents the extinction horizon. Alphabet along the log is unit name. Feix.: Feixianguan; (b) $\delta^{34} S-\Delta^{33} S$ cross plot. A diamond represents the estimated contemporaneous seawater sulfate with the $\delta^{34} S$ and $\Delta^{33} S$ values of $+19.2 \%$ and $+0.022 \%$, respectively [68]. A star shows instantaneously produced sulfide via the seawater sulfate reduction assuming that the ${ }^{34} \varepsilon$ and ${ }^{33} \lambda$ values are $58.1 \%$ and 0.513 , respectively (red arrow), although its $\delta^{34} S$ and $\Delta^{33} S$ values are not strictly constrained (gray circle). Solid black arrows represent the evolution of the remaining sulfate and the instantaneously produced $\mathrm{H}_{2} \mathrm{~S}$, and a black dashed convex upward curve shows the evolution of accumulative $\mathrm{H}_{2} \mathrm{~S}$ produced via MSR in a closed system. Black convex downward curves are a mixing curve between the two endmembers: sulfide produced via quantitative MSR and instantaneously produced $\mathrm{H}_{2} \mathrm{~S}$ in an open system. A number on the curves represents a portion of the latter endmember on the mixing. Fields where disproportionation is required and not required are from Zhang et al. [67]. Note that the negative $\Delta^{33} \mathrm{~S}$ signals are observed in the oxic Wujiaping limestones, as in the case of the G-LB interval at Chaotian (Figure 7). 


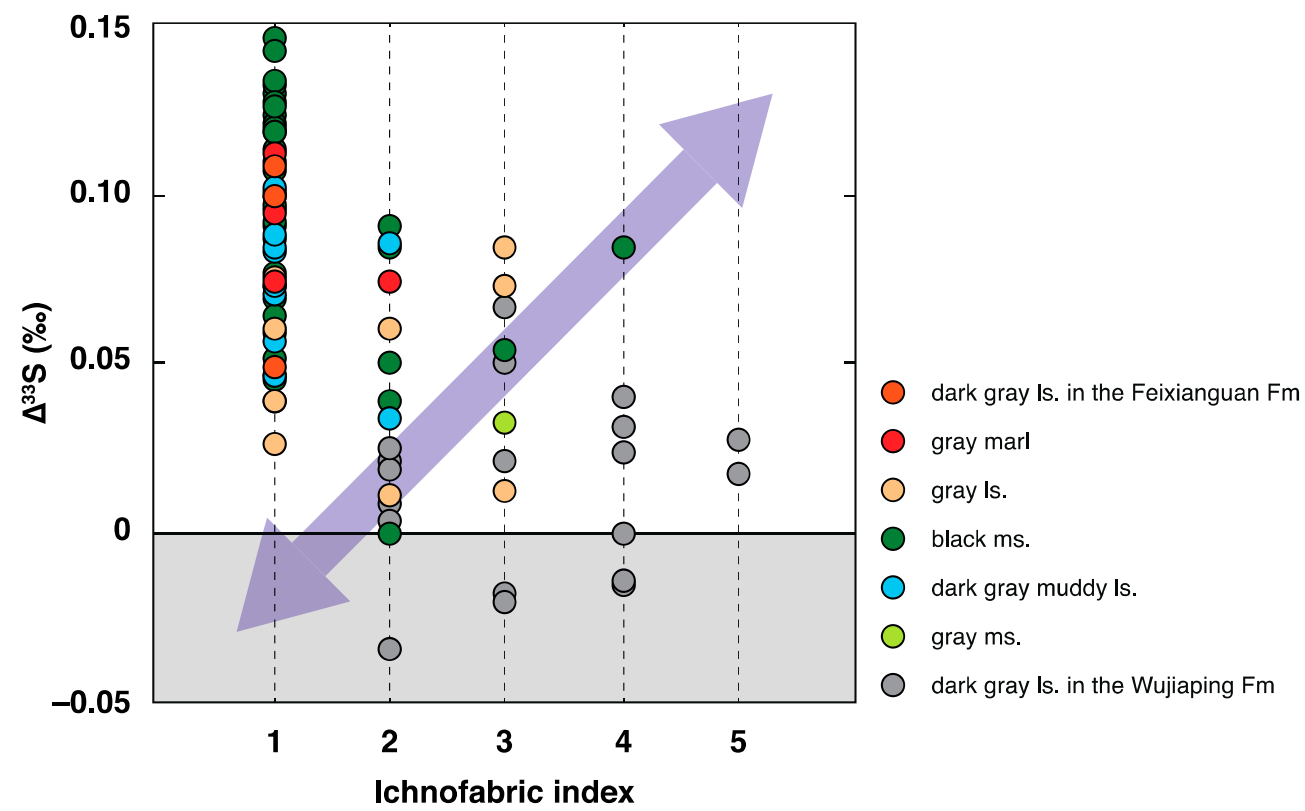

Figure 11. Correlation between $\Delta^{33} \mathrm{~S}$ and ichnofabric index of the P-TB sediments at Chaotian [122]. According to the previous shoaling model $[55,67]$, a positively correlated variation (arrow) would have been observed because the negative $\Delta^{33} S$ signal was restricted to anoxic/sulfidic sediments with no burrows. That is not the Chaotian case.

\section{3. $S-S B$}

Thomazo et al. [125] analyzed the multiple sulfur isotopic composition of sedimentary pyrite across the S-SB at Mineral Mountains in Utah, USA (Figure 1b). In the Early Triassic, the Mineral Mountains section was located in the southern Sonoma Foreland Basin on the western Pangea margin, in which carbonates and marls of the Thaynes Group accumulated [126]. The analyzed 120 -m-thick S-SB interval at Mineral Mountains is subdivided into the unit A, B, SSB, and C, in ascending order (Figure 12a). The $\sim 20$-m-thick unit $\mathrm{A}$ is composed mainly of microbial/bioclastic carbonates accumulated in inter- to sub-tidal settings on an inner ramp. The overlying 50-m-thick unit B is composed mainly of mudstones with storm-induced deposits accumulated in an upper offshore setting on a mid to outer ramp. The overlying 10-m-thick unit SSB is composed of marls accumulated in a lower offshore setting on a mud outer ramp. The uppermost $\sim 40$-m-thick unit $C$ shows an upward shallowing trend, from mudstones accumulated on an outer ramp to microbial carbonates on an outer to mid ramp. The analyzed S-SB interval therefore recorded a transgression-regression cycle, with the maximum flooding event during the deposition of the unit SSB. Although the S-SB is not well assigned, regional litho- and bio-stratigraphic correlations indicated that the unit SSB corresponds to the Smithian-Spathian transition interval $[126,127]$. In spite of the relative sea-level changes, the S-SB interval was deposited consistently under oxic to dysoxic conditions [128]. The common occurrence of trace fossils (except for the unit SSB and the lower part of unit C) and multiple geochemical data indicated the absence of water-column anoxia through the analyzed interval. 

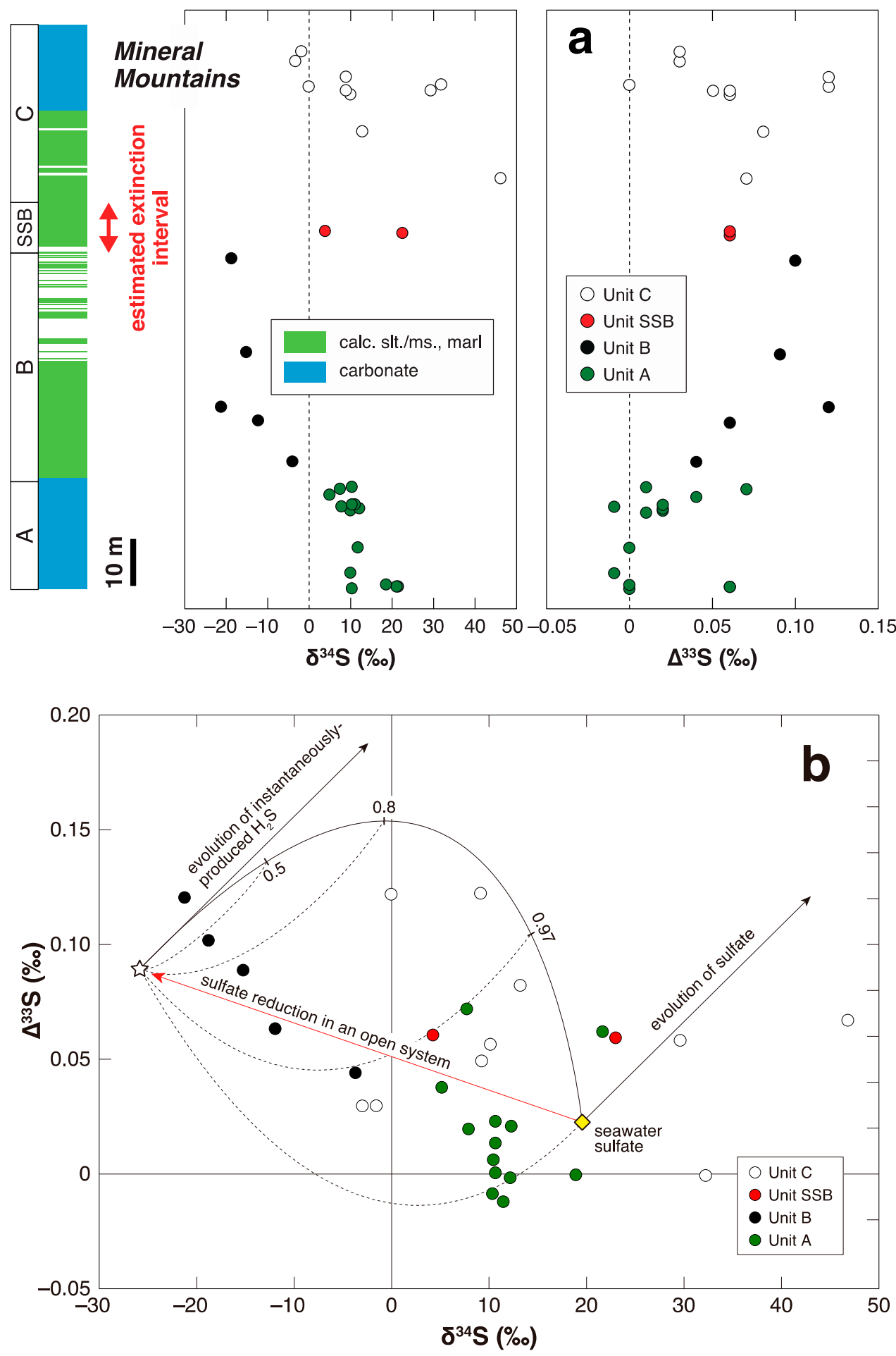

Figure 12. Multiple sulfur isotope record across the S-SB at Mineral Mountains [125]. (a) sulfur isotope chemostratigraphy. The estimated extinction interval is based on regional litho- and bio-stratigraphic correlations [126,127]. Alphabet along the $\log$ is unit name. calc.: calcareous, slt.: siltstone, ms.: mudstone; (b) $\delta^{34} S-\Delta^{33} S$ cross plot. Solid black arrows represent the evolution of the instantaneously produced $\mathrm{H}_{2} \mathrm{~S}$ and the remaining sulfate via reduction of the contemporaneous seawater sulfate [68] in a closed system, assuming that the ${ }^{34} \varepsilon$ and ${ }^{33} \lambda$ values in MSR were $44.8 \%$ and 0.512 (red arrow), respectively. A solid black curve represents the evolution of accumulatively produced $\mathrm{H}_{2} \mathrm{~S}$. A number on the curve is a fraction of sulfate converted to $\mathrm{H}_{2} \mathrm{~S}$. A black dashed curve shows a mixing of accumulative $\mathrm{H}_{2} \mathrm{~S}$ and sulfide produced in an open system (star). Note that the $\delta^{34} S$ values increased from negative in the unit B to positive in the overlying units SSB and C, while the $\Delta^{33} S$ values remained consistently positive. It suggests that the sediments shifted from an open system (unit B) to a close system (units SSB and C) by the shutdown of bioturbation during the late-Smithian extinction event. 
The $\delta^{34} S$ and $\Delta^{33} S$ values of the carbonates in the unit A were relatively high and low, respectively (Figure 12). In particular, some negative $\Delta^{33} S$ values were recorded in the carbonates with burrows. Thomazo et al. [125] explained the sulfur isotope data of the unit A by a mixing of ${ }^{34} \mathrm{~S}$-depleted and ${ }^{34} \mathrm{~S}$-enriched sulfides both produced in the carbonates via MSR. They particularly suggested that benthos activity supplied seawater sulfate into the sediments via burrows and promoted MSR to produce ${ }^{34} \mathrm{~S}$-depleted $\mathrm{H}_{2} \mathrm{~S}$. Their sulfur mixing model was similar to that for the negative $\Delta^{33} S$ data of the bioclastic limestones in the G-LB and P-TB intervals at Chaotian [100,122]. The overlying unit B was characterized by the negative $\delta^{34} S$ and positive $\Delta^{33} S$ values, suggesting MSR under sulfateenriched conditions. Thomazo et al. suggested that ${ }^{34} \mathrm{~S}$-depleted sulfides were produced in the sediments, an open system with respect to sulfate due to the common burrows, as in the case of unit A. In contrast, in the overlying unit SSB and C, the $\delta^{34} S$ values were mostly positive though the $\Delta^{33} S$ values remained high. Thomazo et al. emphasized that the systematic increase in $\delta^{34}$ S from the unit B to the overlying units SSB and C (with the consistently positive $\Delta^{33} \mathrm{~S}$ ) corresponded to the disappearance of trace fossils. They interpreted that the analyzed sediments shifted from an open system to a close system by the shutdown of bioturbation associated with the late Smithian extinction. They further inferred that ${ }^{33} \mathrm{~S}$-enriched accumulative $\mathrm{H}_{2} \mathrm{~S}$ was produced in the closed sediments via partial reduction of porewater sulfate, according to Rayleigh distillation (Figure 12b). The accumulative $\mathrm{H}_{2} \mathrm{~S}$ was mixed with ${ }^{34} \mathrm{~S}$-depleted sulfides produced earlier in the open sediments, resulting in the positive $\delta^{34} S$ and $\Delta^{33} S$ values of bulk sediments in the units SSB and $C$. Their work therefore illustrated a clear correlation between bioturbation and the sedimentary sulfur isotope record during the Smithian-Spathian transition.

\section{Negative $\Delta^{33} S$ Signal as an Indicator of Shoaling?}

Shen Y. et al. [55] and Zhang G.J. et al. $[67,69]$ regarded the negative $\Delta^{33}$ S signature in the sediments as an indicator of shoaling of anoxic/sulfidic deep-water. However, later multiple sulfur isotope studies were apparently inconsistent, at least in part, with the previous shoaling model. For instance, the negative $\Delta^{33} S$ signals were observed in oxic shelf carbonates with common burrows in the G-LB and P-TB intervals at Chaotian $[100,122]$ and in the S-SB interval at Mineral Mountains [125], with the absence of evidence for anoxia. On the other hand, the $\Delta^{33} S$ value of sediment accumulated during shoaling of sulfidic deep-water may not have been necessarily negative. This is because the bulk $\Delta^{33} \mathrm{~S}$ value of euxinic sediment was strongly controlled by a supply of $\mathrm{H}_{2} \mathrm{~S}$ (with positive $\Delta^{33} \mathrm{~S}$ ) to the sediment via shoaling, as observed in the P-TB euxinic shale at Opal Creek [67] and in the earliest Triassic Feixianguan carbonates at Chaotian [122]. Even when the sediments shifted from an open system to a closed system by the shutdown of bioturbation according to the previous model, the bulk $\Delta^{33} S$ value of the sediments could remain positive. As Thomazo et al. [125] demonstrated at Mineral Mountains, when accumulative $\mathrm{H}_{2} \mathrm{~S}$ was produced via partial reduction of porewater sulfate in the closed sediments, its mixing with ${ }^{34} \mathrm{~S}$-depleted sulfides (produced earlier in the open sediments) resulted in the consistently positive $\Delta^{33} \mathrm{~S}$ values of the bulk sediments (Figure 12b). Furthermore, a positively correlated variation between the $\Delta^{33} S$ value and ichnofabric index of the sediments, which would have been expected according to the previous shoaling model, is not observed in the P-TB interval at Chaotian [122].

Additionally, a stratigraphic relationship between the extinction horizon, redox oscillation in the depositional settings, and the negative $\Delta^{33} \mathrm{~S}$ signals in the studied sections does not support the previous shoaling model strongly, although Shen Y. et al. [55] and Zhang G.J. et al. $[67,69]$ emphasized their stratigraphic correspondence. The negative $\Delta^{33} S$ values are observed through the G-LB interval at Penglaitan (Figure 3), and that is apparently consistent with the supposed stepwise extinction in the interval. However, the Laibin Limestone was generally deposited under oxic conditions [74], and it is inconsistent with shoaling of anoxic/sulfidic deep-waters. In the G-LB interval at Tieqiao and at EF, the extinction horizon has been poorly constrained (Figures 4 and 5). At Chaotian, the middle 
to upper Capitanian shelf record is missing (Figure 7a) [100]. In these three sections, it is difficult to ascertain a clear stratigraphic correspondence between the extinction event and negative $\Delta^{33} \mathrm{~S}$ signals. In the maximum extinction interval across the P-TB at Meishan (Figure $2 \mathrm{a}$ ), the $\Delta^{33} \mathrm{~S}$ values are generally positive. The $\Delta^{33} \mathrm{~S}$ values are also consistently positive across the extinction horizon in the P-TB interval at Chaotian (Figure 10a). At Opal Creek, the negative $\Delta^{33} S$ signals are observed at the extinction horizon and that is apparently consistent with the shoaling model (Figure 8a). As the Gujo-Hachiman P-TB sediments accumulated on the deep-ocean floor in mid-Panthalassa, Zhang et al. [67] interpreted that the negative $\Delta^{33} \mathrm{~S}$ values of the abyssal sediments reflected oscillations between sulfidic and oxic conditions in the deep ocean (Figure 9a). However, as discussed in Section 3.2, the redox conditions in the Panthalassan bottom waters during the accumulation of the analyzed Gujo-Hachiman sediments are controversial. The $\Delta^{33} \mathrm{~S}$ values are positive in the SSB unit at Mineral Mountains although there are few analyzed points in the unit (Figure 12) [125].

The present compilation shows that the multiple sulfur isotope records during the Permian-Triassic transition are substantially variable (Figure 13), and that the negative $\Delta^{33} S$ signals are observed in various types of sediments including shallow-marine carbonates, carbonates/siltstones of relatively deep-water facies, and abyssal deep-sea cherts/ siliceous claystones. As Shen Y. et al. [55] and Zhang G.J. et al. [67,69] suggested, the negative $\Delta^{33} S$ values of the sediments are indicative of mixing of ${ }^{34} \mathrm{~S}$-depleted and ${ }^{34} \mathrm{~S}$-enriched sulfur [50]. Nonetheless, the negative $\Delta^{33} S$ records observed in various depositional environments strongly suggest that the supposed sulfur mixing is not unambiguously associated with a shoaling scenario. Under the circumstances, the negative $\Delta^{33} \mathrm{~S}$ signal may not be a robust indicator of shoaling of anoxic/sulfidic deep-waters. Although the shoaling model in Shen Y. et al. [55] and Zhang G.J. et al. [69] is fascinating, the sedimentary sulfur cycle during the Permian-Triassic transition interval may have been more complicated than originally thought.
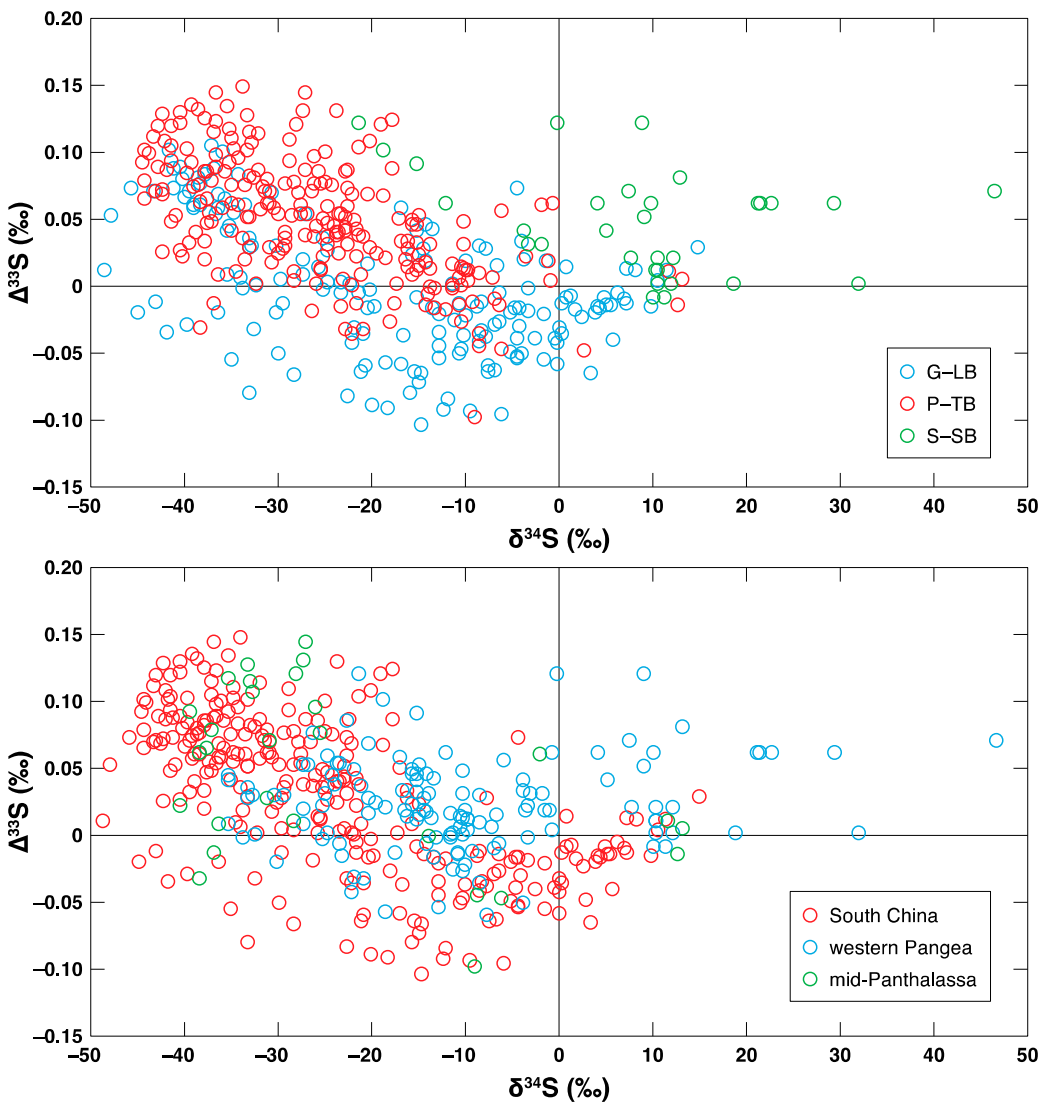

Figure 13. Cont. 


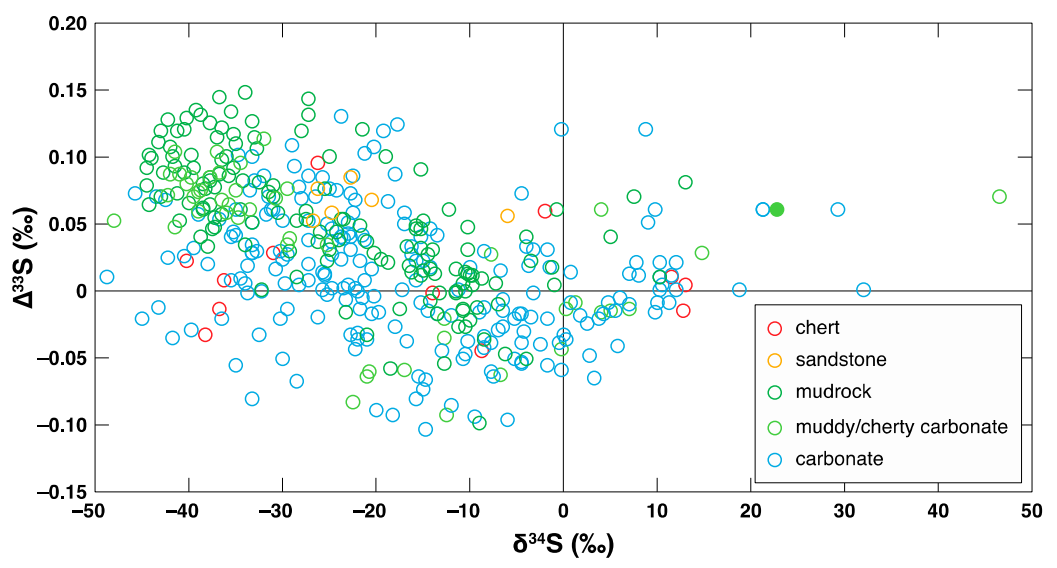

Figure 13. Multiple sulfur isotope records during the Permian-Triassic transition interval. Note that the negative $\Delta^{33} \mathrm{~S}$ signals were detected in various types of sediments.

\section{Future Perspectives}

Several topics remain to be examined in future to better constrain the sedimentary sulfur cycle in association with bottom water redox during the Permian-Triassic transition.

\subsection{Correlation between the Benthic Redox Conditions and $\Delta^{33} S$ Records}

A stratigraphic relationship between the benthic redox conditions, benthos activity, and the multiple sulfur isotopic composition of sedimentary pyrite should be examined in more detail. So far, Saitoh et al. [122] is the only study that examined a stratigraphic correlation between the $\Delta^{33} S$ value and ichnofabric index of the sediments. Clarkson et al. [129] reported iron speciation data of shelf to basin sediments in several sections along the Arabian Margin, and suggested that anoxic ferruginous (non-sulfidic) conditions were prevalent in Neotethys during the Lopingian to Early Triassic. Those Neotethyan "ferruginous" sediments would be an interesting target for a future multiple sulfur isotope study because those sediments may have recorded pristine isotopic signatures of the sedimentary sulfur cycle for the following reasons. When the sediments were overlain by the ferruginous water column, the oxidation of $\mathrm{H}_{2} \mathrm{~S}$ produced via sedimentary MSR may have been suppressed under oxygen-depleted conditions. The escape of $\mathrm{H}_{2} \mathrm{~S}$ from the sediments to the overlying water column may also have been prevented. Instead, $\mathrm{H}_{2} \mathrm{~S}$ would have precipitated as iron sulfide at or below the sediment-water interface, although Clarkson et al. [129] did not specify that the bottom waters were enriched in ferrous ion on the analyzed sediments. On the other hand, the addition of sulfide from the overlying ferruginous water column to the sediments (e.g., liberated $\mathrm{H}_{2} \mathrm{~S}$ and sinking pyrite framboids) may have been substantially limited. Furthermore, the sediments would not have been disturbed by bioturbation under oxygen-depleted conditions. Hence, the Neotethyan "ferruginous" sediments would be a good recorder of the intrinsic sedimentary sulfur cycle during the Lopingian to Early Triassic.

\subsection{SIMS Sulfur Isotope Record}

Multiple sulfur isotope measurements by SIMS are useful for identifying a microscopic isotopic variation in sedimentary sulfide (e.g., $[130,131])$, although SIMS sulfur isotope records in the Permian-Triassic transition interval have not yet been reported. The reproducibility for $\Delta^{33}$ S in SIMS analyses (generally $2 \sigma>0.1 \%$; cf., [132]) is too large to detect the $\Delta^{33} S$ variation in the Permian-Triassic sediments, while that for $\delta^{34} S$ (generally $2 \sigma<0.5 \%$ ) is small enough to identify local $\delta^{34} S$ heterogeneity in the sediments. In particular, the previous bulk studies interpreted that the obtained negative $\Delta^{33} S$ records were a result of mixing of ${ }^{34}$ S-depleted and ${ }^{34}$ S-enriched sulfur in the analyzed sediments (e.g., $\left.[55,69,100]\right)$. In other words, those studies assumed the coexistence of ${ }^{34} \mathrm{~S}$-depleted and ${ }^{34} \mathrm{~S}$-enriched sulfur in the analyzed rock samples at the hand-specimen scale. To verify the sulfur mixing 
model in the bulk studies, it will be important to examine the supposed substantial $\delta^{34} \mathrm{~S}$ variation in the sediments during the Permian-Triassic transition by SIMS.

It is worth noting that some pyrite grains occur within a burrow in shelf limestones in the Permian-Triassic transition (see Figure 3a in Saitoh et al. [122], for example). According to the sulfur mixing model in Saitoh et al. [100], these pyrites were produced in situ within the burrows, a local open system connected to the sulfate-enriched water column, and thus their $\delta^{34} S$ values are substantially low. A systematic difference in $\delta^{34} \mathrm{~S}$ value between sulfides within the burrows and in the matrix in the same rock samples would be identified by future SIMS analyses. However, Harazim et al. [133] reported anomalously ${ }^{34}$ S-enriched pyrites in burrows in Early Ordovician delta sediments in Newfoundland, Canada. The $\delta^{34} S$ values of pyrites within the burrows in the mudstones analyzed by SIMS were substantially scattered, ranging from $+16 \%$ o to $+58 \%$ with the average value of $\sim+40 \%$, but somewhat higher than the bulk $\delta^{34} \mathrm{~S}$ values of the sediments $(+13 \%$ o to $+42 \%$ ) and the estimated $\delta^{34} \mathrm{~S}$ value of contemporary seawater sulfate (between $+30 \%$ and $+40 \%$ ). These data indicated that some pyrites precipitated in a closed system during a Rayleigh-type distillation of the residual sulfate pool, and that the burrows were, at least in part, a closed system with respect to sulfate. Their results were therefore apparently inconsistent with the prediction by Saitoh et al. [100].

By using nanoSIMS, Wang et al. [134] recently reported a clear correlation between $\delta^{34} S$ value and morphology of pyrite in the Ediacaran strata in South China. In the analyzed shales/carbonates, syndepositional pyrite framboids were characterized by substantially low $\delta^{34} S$ values (up to $-40 \%$ ), possibly produced in the anoxic water column/sediments. In contrast, diagenetic euhedral to subhedral pyrites were characterized by high $\delta^{34} \mathrm{~S}$ values (up to $+40 \%$ ), produced in the closed sediments according to Rayleigh distillation. The bulk $\delta^{34} S$ values of the analyzed sediments were intermediate between the values of pyrite framboids and of euhedral to subhedral pyrites, showing that the bulk values were determined by a mixing of the two distinct types of pyrite. Although the relationship between the morphology and sulfur isotopic composition of pyrite could have been complicated by authigenic overgrowth on syndepositional sulfides (cf., [135]), their results showed the coexistence of ${ }^{34} \mathrm{~S}$-depleted and ${ }^{34} \mathrm{~S}$-enriched sulfides in the same sediments. It is also worth noting that the analyzed sediments accumulated in the Ediacaran and thus bore no burrows. Their results were apparently consistent with the shoaling model in Zhang G.J. et al. $[67,69]$, in which the coexistence of ${ }^{34}$ S-depleted and ${ }^{34}$ S-enriched sulfides was associated with the absence of bioturbation. At any rate, a microscopic isotopic variation in sedimentary sulfide during the Permian-Triassic transition should be examined by SIMS analyses in future.

\subsection{Negative $\Delta^{33} S$ Record during the Phanerozoic}

The present compilation shows that the negative $\Delta^{33} \mathrm{~S}$ signals are observed in various depositional environments from a shallow shelf to an abyssal plain (Figure 13). Besides the Permian-Triassic transition interval, the negative $\Delta^{33} S$ signatures of sedimentary pyrite were recently found in the Ediacaran-Cambrian transition [136], in the Ordovician [137], and in the Triassic-Jurassic transition [138]. Although further works are required, the negative $\Delta^{33} S$ records may prevail more widely than previously thought in the Phanerozoic. If the negative $\Delta^{33} \mathrm{~S}$ signatures would be observed commonly in the Phanerozoic sediments, they should be attributed to a common sedimentary/diagenetic process, not a peculiar one like shoaling of toxic deep-water. Recent studies have extensively emphasized heterogeneity in the sulfur isotopic composition of pyrite in a sediment and in a single sedimentary system, largely controlled by local/diagenetic factors (e.g., $[133,134,139,140])$. Those observations allow me to infer that the sedimentary negative $\Delta^{33} \mathrm{~S}$ records during the Permian-Triassic transition interval (and possibly in the entire Phanerozoic) reflect local sulfur isotope heterogeneity in the sediments, rather than shoaling of anoxic/sulfidic deep-waters on a global scale. This idea is testable by examining how the negative $\Delta^{33} \mathrm{~S}$ signals prevail in the Phanerozoic sedimentary records in future. 
Funding: This research received no external funding.

Institutional Review Board Statement: Not applicable.

Informed Consent Statement: Not applicable.

Acknowledgments: Two anonymous reviewers gave me fruitful comments to improve the manuscript.

Conflicts of Interest: The author declares no conflict of interest.

\section{References}

1. Alroy, J. The shifting balance of diversity among major marine animal groups. Science 2010, 329, 1191-1194. [CrossRef] [PubMed]

2. Shen, S.Z.; Crowley, J.L.; Wang, Y.; Bowring, S.A.; Erwin, D.H.; Sadler, P.M.; Cao, C.Q.; Rothman, D.H.; Henderson, C.M.; Ramezani, J.; et al. Calibrating the End-Permian Mass Extinction. Science 2011, 334, 1367-1372. [CrossRef] [PubMed]

3. Erwin, D.H. Extinction: How Life on Earth Nearly Ended 250 Million Years Ago, Updated ed.; Princeton Univ. Press: Princeton, NJ, USA, 2015; pp. 1-296.

4. Yin, H.F.; Feng, Q.L.; Lai, X.L.; Baud, A.; Tong, J.N. The protracted Permo-Triassic crisis and multi-episode extinction around the Permian-Triassic boundary. Glob. Planet. Chang. 2007, 55, 1-20. [CrossRef]

5. Isozaki, Y. Permo-Triassic boundary superanoxia and stratified superocean: Records from lost deep sea. Science 1997, 276, 235-238. [CrossRef] [PubMed]

6. Isozaki, Y. Integrated "plume winter" scenario for the double-phased extinction during the Paleozoic-Mesozoic transition: The G-LB and P-TB events from a Panthalassan perspective. J. Asian Earth Sci. 2009, 36, 459-480. [CrossRef]

7. Jin, Y.G.; Zhang, J.; Shang, Q.H. Two phases of the end-Permian mass extinction. In Pangea: Global Environments and Resources; Embry, A.F., Beauchamp, B., Glass, D.J., Eds.; Canadian Society of Petroleum Geologists: Calgary, AB, Canada, 1994; Volume 17, pp. 813-822.

8. Stanley, S.M.; Yang, X. A double mass extinction at the end of the Paleozoic era. Science 1994, 266, 1340-1344. [CrossRef]

9. Rampino, M.R.; Shen, S.Z. The end-Guadalupian (259.8 Ma) biodiversity crisis: The sixth major mass extinction? Hist. Biol. 2021, 33, 716-722. [CrossRef]

10. Hallam, A. Why was there a delayed radiation after the end-Palaeozoic extinctions? Hist. Biol. 1991, 5, 257-262. [CrossRef]

11. Galfetti, T.; Hochuli, P.A.; Brayard, A.; Bucher, H.; Weissert, H.; Vigran, J.O. Smithian-Spathian boundary event: Evidence for global climatic change in the wake of the end-Permian biotic crisis. Geology 2007, 35, 291-294. [CrossRef]

12. Zhang, L.; Orchard, M.J.; Brayard, A.; Algeo, T.J.; Zhao, L.; Chen, Z.Q.; Lyu, Z. The Smithian/Spathian boundary (late Early Triassic): A review of ammonoid, conodont, and carbon-isotopic criteria. Earth-Sci. Rev. 2019, 195, 7-36. [CrossRef]

13. Zhou, M.F.; Malpas, J.; Song, X.Y.; Robinson, P.T.; Sun, M.; Kennedy, A.K.; Lesher, C.M.; Keays, R.R. A temporal link between the Emeishan large igneous province (SW China) and the end-Guadalupian mass extinction. Earth Planet. Sci. Lett. 2002, 196, 113-122. [CrossRef]

14. Wignall, P.B.; Sun, Y.D.; Bond, D.P.G.; Izon, G.; Newton, R.J.; Vedrine, S.; Widdowson, M.; Ali, J.R.; Lai, X.L.; Jiang, H.S.; et al. Volcanism, mass extinction, and carbon isotope fluctuations in the Middle Permian of China. Science 2009, 324, 1179-1182. [CrossRef]

15. Isozaki, Y.; Kawahata, H.; Ota, A. A unique carbon isotope record across the Guadalupian-Lopingian (Middle-Upper Permian) boundary in mid-oceanic paleoatoll carbonates: The high-productivity "Kamura event" and its collapse in Panthalassa. Glob. Planet. Chang. 2007, 55, 21-38. [CrossRef]

16. Saitoh, M.; Isozaki, Y.; Yao, J.X.; Ji, Z.S.; Ueno, Y.; Yoshida, N. The appearance of an oxygen-depleted condition on the Capitanian disphotic slope/basin in South China: Middle-upper Permian stratigraphy at Chaotian in northern Sichuan. Glob. Planet. Chang. 2013, 105, 180-192. [CrossRef]

17. Saitoh, M.; Isozaki, Y.; Ueno, Y.; Yoshida, N.; Yao, J.X.; Ji, Z.S. Middle-Upper Permian carbon isotope stratigraphy at Chaotian, South China: Pre-extinction multiple upwelling of oxygen-depleted water onto continental shelf. J. Asian Earth Sci. 2013, 67-68, 51-62. [CrossRef]

18. Yan, D.; Liqin, Z.; Zhen, Q. Carbon and sulfur isotopic fluctuations associated with the end-Guadalupian mass extinction in South China. Gondwana Res. 2013, 24, 1276-1282. [CrossRef]

19. Becker, L.; Poreda, R.J.; Hunt, A.G.; Bunch, T.E.; Rampino, M. Impact event at the Permian-Triassic boundary: Evidence from extraterrestrial noble gases in fullerenes. Science 2001, 291, 1530-1533. [CrossRef]

20. Renne, P.R.; Basu, A.R. Rapid eruption of the Siberian traps flood basalts at the Permian-Triassic boundary. Science 1991, 253, 176-179. [CrossRef] [PubMed]

21. Reichow, M.K.; Pringle, M.S.; Al'Mukhamedov, A.I.; Allen, M.B.; Andreichev, V.L.; Buslov, M.M.; Davies, C.E.; Fedoseev, G.S.; Fitton, J.G.; Inger, S.; et al. The timing and extent of the eruption of the Siberian Traps large igneous province: Implications for the end-Permian environmental crisis. Earth Planet Sci. Lett. 2009, 277, 9-20. [CrossRef]

22. Joachimski, M.M.; Lai, X.L.; Shen, S.Z.; Jiang, H.S.; Luo, G.M.; Chen, B.; Chen, J.; Sun, Y. Climate warming in the latest Permian and the Permian-Triassic mass extinction. Geology 2012, 40, 195-198. [CrossRef]

23. Wignall, P.B.; Hallam, A. Anoxia as a cause of the Permian/Triassic mass extinction: Facies evidence from northern Italy and the western United States. Palaeogeogr. Palaeoclimatol. Palaeoecol. 1992, 93, 21-46. [CrossRef] 
24. Kump, L.R.; Pavlov, A.; Arthur, M.A. Massive release of hydrogen sulfide to the surface ocean and atmosphere during intervals of oceanic anoxia. Geology 2005, 33, 397-400. [CrossRef]

25. Knoll, A.H.; Bambach, R.K.; Payne, J.L.; Pruss, S.; Fischer, W.W. Paleophysiology and end-Permian mass extinction. Earth Planet Sci. Lett. 2007, 256, 295-313. [CrossRef]

26. Clarkson, M.O.; Kasemann, S.A.; Wood, R.A.; Lenton, T.M.; Daines, S.J.; Richoz, S.; Ohnemueller, F.; Meixner, A.; Poulton, S.W.; Tipper, E.T. Ocean acidification and the Permo-Triassic mass extinction. Science 2015, 348, 229-232. [CrossRef]

27. Payne, J.L.; Kump, L.R. Evidence for recurrent Early Triassic massive volcanism from quantitative interpretation of carbon isotope fluctuations. Earth Planet. Sci. Lett. 2007, 256, 264-277. [CrossRef]

28. Cui, Y.; Kump, L.R. Global warming and the end-Permian extinction event: Proxy and modeling perspectives. Earth-Sci. Rev. 2015, 149, 5-22. [CrossRef]

29. Jurikova, H.; Gutjahr, M.; Wallmann, K.; Flögel, S.; Liebetrau, V.; Posenato, R.; Angiolini, L.; Garbelli, C.; Brand, U.; Wiedenbeck, M.; et al. Permian-Triassic mass extinction pulses driven by major marine carbon cycle perturbations. Nat. Geosci. 2020, 13, 745-750. [CrossRef]

30. Wu, Y.Y.; Chu, D.L.; Tong, J.N.; Song, H.J.; Corso, J.D.; Wignall, P.B.; Song, H.Y.; Du, Y.; Cui, Y. Six-fold increase of atmospheric $\mathrm{pCO}_{2}$ during the Permian-Triassic mass extinction. Nat. Commun. 2021, 12, 2137. [CrossRef] [PubMed]

31. Retallack, G.J.; Jahren, A.H. Methane release from igneous intrusion of coal during Late Permian extinction events. J. Geol. 2008, 116, 1-20. [CrossRef]

32. Saitoh, M.; Isozaki, Y. Carbon isotope chemostratigraphy across the Permian-Triassic boundary at Chaotian, China: Implications for the global methane cycle in the aftermath of the extinction. Front. Earth Sci. 2021, 8, 596178. [CrossRef]

33. Sun, Y.; Joachimski, M.M.; Wignall, P.B.; Yan, C.; Chen, Y.; Jiang, H.; Wang, L.; Lai, X.L. Lethally hot temperatures during the Early Triassic greenhouse. Science 2012, 338, 366-370. [CrossRef]

34. Song, H.J.; Song, H.Y.; Tong, J.N.; Gordon, G.W.; Wignall, P.B.; Tian, L.; Zheng, W.; Algeo, T.J.; Liang, L.; Bai, R.Y.; et al. Conodont calcium isotopic evidence for multiple shelf acidification events during the Early Triassic. Chem. Geol. 2021, 562, 120038. [CrossRef]

35. Grasby, S.E.; Beauchamp, B.; Embry, A.; Sanei, H. Recurrent Early Triassic ocean anoxia. Geology 2013, 41, 175-178. [CrossRef]

36. Lau, K.V.; Maher, K.; Altiner, D.; Kelley, B.M.; Kump, L.R.; Lehrmann, D.J.; Silva-Tamayo, J.C.; Weaver, K.L.; Yu, M.; Payne, J.L. Marine anoxia and delayed Earth system recovery after the end-Permian extinction. Proc. Natl. Acad. Sci. USA 2016, 113, 2360-2365. [CrossRef] [PubMed]

37. Zhang, F.F.; Romaniello, S.J.; Algeo, T.J.; Lau, K.V.; Clapham, M.E.; Richoz, S.; Herrmann, A.D.; Smith, H.; Horacek, M.; Anbar, A.D. Multiple episodes of extensive marine anoxia linked to global warming and continental weathering following the latest Permian mass extinction. Sci. Adv. 2018, 4, e1602921. [CrossRef]

38. Brayard, A.; Bucher, H.; Escarguel, G.; Fluteau, F.; Bourquin, S.; Galfetti, T. The Early Triassic ammonoid recovery: Paleoclimatic significance of diversity gradients. Palaeogeogr. Palaeoclimatol. Palaeoecol. 2006, 239, 374-395. [CrossRef]

39. Stanley, S.M. Evidence from ammonoids and conodonts for multiple Early Triassic mass extinctions. Proc. Natl. Acad. Sci. USA 2009, 106, 15264-15267. [CrossRef] [PubMed]

40. Grasby, S.E.; Sanei, H.; Beauchamp, B.; Chen, Z.H. Mercury deposition through the Permo-Triassic Biotic Crisis. Chem. Geol. 2013, 351, 209-216. [CrossRef]

41. Payne, J.L.; Lehrmann, D.J.; Wei, J.Y.; Orchard, M.J.; Schrag, D.P.; Knoll, A.H. Large perturbations of the carbon cycle during recovery from the end-Permian extinction. Science 2004, 305, 506-509. [CrossRef]

42. Romano, C.; Goudemand, N.; Vennemann, T.W.; Ware, D.; Schneebeli-Hermann, E.; Hochuli, P.A.; Brühwiler, T.; Brinkmann, W.; Bucher, H. Climatic and biotic upheavals following the end-Permian mass extinction. Nat. Geosci. 2013, 6, 57-60. [CrossRef]

43. Song, H.Y.; Du, Y.; Algeo, T.J.; Tong, J.N.; Owens, J.D.; Song, H.J.; Tian, L.; Qiu, H.; Zhu, Y.Y.; Lyons, T.W. Cooling-driven oceanic anoxia across the Smithian/Spathian boundary (mid-Early Triassic). Earth-Sci. Rev. 2019, 195, 133-146. [CrossRef]

44. Payne, J.L.; Clapham, M.E. End-Permian mass extinction in the oceans: An ancient analog for the twenty-first century? Ann. Rev. Earth Planet. Sci. 2012, 40, 89-111. [CrossRef]

45. Farquhar, J.; Wing, B.A. Multiple sulfur isotopes and the evolution of the atmosphere. Earth Planet. Sci. Lett. 2003, 213, 1-13. [CrossRef]

46. Johnston, D.T. Multiple sulfur isotopes and the evolution of Earth's surface sulfur cycle. Earth-Sci. Rev. 2011, 106, 161-183. [CrossRef]

47. Ovtcharova, M.; Bucher, H.; Schaltegger, U.; Galfetti, T.; Brayard, A.; Guex, J. New Early to Middle Triassic U-Pb ages from South China: Calibration with ammonoid biochronozones and implications for the timing of the Triassic biotic recovery. Earth Planet. Sci. Lett. 2006, 243, 463-475. [CrossRef]

48. Gradstein, F.M.; Ogg, J.G.; Schmitz, M.D.; Ogg, G.M. Geologic Time Scale 2020; Elsevier: Amsterdam, The Netherlands, 2020; pp. 1-1357.

49. Muttoni, G.; Gaetani, M.; Kent, D.V.; Sciunnach, D.; Angiolini, L.; Berra, F.; Garzanti, E.; Mattei, M.; Zanchi, A. Opening of the Neo-Tethys Ocean and the Pangea B to Pangea A transformation during the Permian. GeoArabia 2009, 14, 17-48. [CrossRef]

50. Ono, S.; Wing, B.; Johnston, D.; Farquhar, J.; Rumble, D. Mass-dependent fractionation of quadruple stable sulfur isotope system as a new tracer of sulfur biogeochemical cycles. Geochim. Cosmochim. Acta 2006, 70, 2238-2252. [CrossRef]

51. Farquhar, J.; Bao, H.M.; Thiemens, M. Atmospheric influence of Earth's earliest sulfur cycle. Science 2000, 289, 756-758. [CrossRef] 
52. Ono, S. Photochemistry of sulfur dioxide and the origin of mass-independent isotope fractionation in Earth's atmosphere. Ann. Rev. Earth Planet. Sci. 2017, 45, 301-329. [CrossRef]

53. Johnston, D.T.; Wing, B.A.; Farquhar, J.; Kaufman, A.J.; Strauss, H.; Lyons, T.W.; Kah, L.C.; Canfield, D.E. Active Microbial Sulfur Disproportionation in the Mesoproterozoic. Science 2005, 310, 1477-1479. [CrossRef] [PubMed]

54. Sim, M.S.; Bosak, T.; Ono, S. Large sulfur isotope fractionation does not require disproportionation. Science 2011, $333,74-77$. [CrossRef]

55. Shen, Y.; Farquhar, J.; Zhang, H.; Masterson, A.; Zhang, T.G.; Wing, B.A. Multiple S-isotopic evidence for episodic shoaling of anoxic water during Late Permian mass extinction. Nature Commun. 2011, 2, 210. [CrossRef] [PubMed]

56. Yin, H.F.; Zhang, K.; Tong, J.N.; Yang, Z.Y.; Wu, S.B. The Global Stratotype Section and Point (GSSP) of the Permian-Triassic Boundary. Episodes 2001, 24, 102-114.

57. Jin, Y.G.; Wang, Y.; Wang, W.; Shang, Q.H.; Cao, C.Q.; Erwin, D.H. Pattern of marine mass extinction near the Permian-Triassic boundary in South China. Science 2000, 289, 432-436. [CrossRef] [PubMed]

58. Wignall, P.B.; Hallam, A. Griesbachian (Earliest Triassic) palaeoenvironmental changes in the Salt Range, Pakistan and southeast China and their bearing on the Permo-Triassic mass extinction. Palaeogeogr. Palaeoclimatol. Palaeoecol. 1993, 102, $215-237$. [CrossRef]

59. Yin, H.F.; Jiang, H.S.; Xia, W.C.; Feng, Q.L.; Zhang, N.; Shen, J. The end-Permian regression in South China and its implication on mass extinction. Earth-Sci. Rev. 2014, 137, 19-33. [CrossRef]

60. Baud, A.; Magaritz, M.; Holser, W.T. Permian-Triassic of the Tethys: Carbon isotope studies. Geol. Rundsch. 1989, 78, 649-677. [CrossRef]

61. Grice, K.; Cao, C.Q.; Love, G.D.; Böttcher, M.E.; Twitchett, R.J.; Grosjean, E.; Summons, R.E.; Turgeon, S.C.; Dunning, W.; Jin, Y.G. Photic zone euxinia during the Permian-Triassic superanoxic event. Science 2005, 307, 706-709. [CrossRef] [PubMed]

62. Li, G.S.; Wang, Y.B.; Shi, G.R.; Liao, W.; Yu, L. Fluctuations of redox conditions across the Permian-Triassic boundary-New evidence from the GSSP section in Meishan of South China. Palaeogeogr. Palaeoclimatol. Palaeoecol. 2016, 448, 48-58. [CrossRef]

63. Hinojosa, J.L.; Brown, S.T.; Chen, J.; DePaolo, D.J.; Paytan, A.; Shen, S.Z.; Payne, J.L. Evidence for end-Permian ocean acidification from calcium isotopes in biogenic apatite. Geology 2012, 40, 743-746. [CrossRef]

64. Grasby, S.E.; Shen, W.J.; Yin, R.S.; Gleason, J.D.; Blum, J.D.; Lepak, R.F.; Hurley, J.P.; Beauchamp, B. Isotopic signatures of mercury contamination in latest Permian oceans. Geology 2017, 45, 55-58. [CrossRef]

65. Song, H.J.; Wignall, P.B.; Tong, J.N.; Yin, H.F. Two pulses of extinction during the Permian-Triassic crisis. Nat. Geosci. 2013, 6, 52-56. [CrossRef]

66. Yin, H.F.; Xie, S.C.; Luo, G.M.; Algeo, T.J.; Zhang, K. Two episodes of environmental change at the Permian-Triassic boundary of the GSSP section Meishan. Earth-Sci. Rev. 2012, 115, 163-172. [CrossRef]

67. Zhang, G.J.; Zhang, X.L.; Hu, D.P.; Li, D.D.; Algeo, T.J.; Farquhar, J.; Henderson, C.M.; Qin, L.P.; Shen, M.; Shen, D.; et al. Redox chemistry changes in the Panthalassic Ocean linked to the end-Permian mass extinction and delayed Early Triassic biotic recovery. Proc. Natl. Acad. Sci. USA 2017, 114, 1806-1810. [CrossRef]

68. Wu, N.P.; Farquhar, J.; Strauss, H.; Kim, S.T.; Canfield, D.E. Evaluating the S-isotope fractionation associated with Phanerozoic pyrite burial. Geochim. Cosmochim. Acta 2010, 74, 2053-2071. [CrossRef]

69. Zhang, G.J.; Zhang, X.L.; Li, D.D.; Farquhar, J.; Shen, S.Z.; Chen, X.Y.; Shen, Y. Widespread shoaling of sulfidic waters linked to the end-Guadalupian (Permian) mass extinction. Geology 2015, 43, 1091-1094. [CrossRef]

70. Jin, Y.G.; Mei, S.L.; Wang, W.; Wang, X.D.; Shen, S.Z.; Shang, Q.H.; Chen, Z.Q. On the Lopingian Series of the Permian system. In Permian Stratigraphy, Environments and Resources; Jin, Y.G., Wardlaw, B.R., Wang, Y., Eds.; China University of Science and Technology Press: Hefei, China, 1998; Volume 9, pp. 1-18.

71. Jin, Y.G.; Shen, S.Z.; Henderson, C.M.; Wang, X.D.; Wang, W.; Wang, Y.; Cao, C.Q.; Shang, Q.H. The Global Stratotype Section and Point (GSSP) for the boundary between the Capitanian and Wuchiapingian Stage (Permian). Episodes 2006, $29,253-262$. [CrossRef]

72. Shen, S.Z.; Wang, Y.; Henderson, C.M.; Cao, C.Q.; Wang, W. Biostratigraphy and lithofacies of the Permian System in the Laibin-Heshan area of Guangxi, South China. Palaeoworld 2007, 16, 120-139. [CrossRef]

73. Qiu, Z.; Wang, Q.C.; Zou, C.N.; Yan, D.; Wei, H.Y. Transgressive-regressive sequences on the slope of an isolated carbonate platform (Middle-Late Permian, Laibin, South China). Facies 2014, 60, 327-345. [CrossRef]

74. Wei, H.Y.; Wei, X.M.; Qiu, Z.; Song, H.Y.; Shi, G. Redox conditions across the G-L boundary in South China: Evidence from pyrite morphology and sulfur isotopic compositions. Chem. Geol. 2016, 440, 1-14. [CrossRef]

75. Wignall, P.B.; Védrine, S.; Bond, D.P.G.; Wang, W.; Lai, X.L.; Ali, J.R.; Jiang, H.S. Facies analysis and sea-level change at the Guadalupian-Lopingian Global Stratotype (Laibin, South China), and its bearing on the end-Guadalupian mass extinction. J. Geol. Soc. 2009, 166, 655-666. [CrossRef]

76. Ehiro, M.; Shen, S.Z. Permian ammonoid Kufengoceras from the uppermost Maokou Formation (earliest Wuchiapingian) at Penglaitan, Laibin Area, Guangxi Autonomous Region, South China. Paleontol. Res. 2008, 12, 255-259. [CrossRef]

77. Ehiro, M.; Shen, S.Z. Ammonoid succession across the Wuchiapingian/Changhsingian boundary of the northern Penglaitan Section in the Laibin area, Guangxi, South China. Geol. J. 2010, 45, 162-169. [CrossRef]

78. Kaiho, K.; Chen, Z.Q.; Ohashi, T.; Arinobu, T.; Sawada, K.; Cramer, B.S. A negative carbon isotope anomaly associated with the earliest Lopingian (Late Permian) mass extinction. Palaeogeogr. Palaeoclimatol. Palaeoecol. 2005, 223, 172-180. [CrossRef] 
79. Shen, S.Z.; Shi, G.R. Latest Guadalupian brachiopods from the Guadalupian/Lopingian boundary GSSP section at Penglaitan in Laibin, Guangxi, South China and implications for the timing of the pre-Lopingian crisis. Palaeoworld 2009, 18, 152-161. [CrossRef]

80. Huang, Y.G.; Chen, Z.Q.; Wignall, P.B.; Grasby, S.E.; Zhao, L.S.; Wang, X.D.; Kaiho, K. Biotic responses to volatile volcanism and environmental stresses over the Guadalupian-Lopingian (Permian) transition. Geology 2019, 47, 175-178. [CrossRef]

81. Yang, X.N.; Liu, J.R.; Shi, G.J. Extinction process and patterns of Middle Permian Fusulinaceans in southwest China. Lethaia 2004, 37, 139-147. [CrossRef]

82. Clapham, M.E.; Shen, S.Z.; Bottjer, D.J. The double mass extinction revisited: Reassessing the severity, selectivity, and causes of the end-Guadalupian biotic crisis (Late Permian). Paleobiology 2009, 35, 32-50. [CrossRef]

83. Groves, J.R.; Wang, Y. Timing and Size Selectivity of the Guadalupian (Middle Permian) Fusulinoidean Extinction. J. Paleontol. 2013, 87, 183-196. [CrossRef]

84. Arefifard, S.; Payne, J.L. End-Guadalupian extinction of larger fusulinids in central Iran and implications for the global biotic crisis. Palaeogeogr. Palaeoclimatol. Palaeoecol. 2020, 550, 109743. [CrossRef]

85. Bond, D.P.G.; Wignall, P.B.; Wang, W.; Izon, G.; Jiang, H.S.; Lai, X.L.; Sun, Y.D.; Newton, R.J.; Shao, L.Y.; Védrine, S.; et al. The mid-Capitanian (Middle Permian) mass extinction and carbon isotope record of South China. Palaeogeogr. Palaeoclimatol. Palaeoecol. 2010, 292, 282-294. [CrossRef]

86. Bond, D.P.G.; Hilton, J.; Wignall, P.B.; Ali, J.R.; Stevens, L.G.; Sun, Y.D.; Lai, X.L. The Middle Permian (Capitanian) mass extinction on land and in the oceans. Earth-Sci. Rev. 2010, 102, 100-116. [CrossRef]

87. Zhang, B.; Yao, S.; Wignall, P.B.; Hu, W.X.; Liu, B.; Ren, Y. New timing and geochemical constraints on the Capitanian (Middle Permian) extinction and environmental changes in deep-water settings: Evidence from the Lower Yangtze region of South China. J. Geol. Soc. 2019, 176, 588-608. [CrossRef]

88. Sun, Y.D.; Liu, X.T.; Yan, J.X.; Li, B.; Chen, B.; Bond, D.P.G.; Joachimski, M.M.; Wignall, P.B.; Wang, X.; Lai, X.L. Permian (Artinskian to Wuchapingian) conodont biostratigraphy in the Tieqiao section, Laibin area, South China. Palaeogeogr. Palaeoclimatol. Palaeoecol. 2017, 465, 42-63. [CrossRef]

89. Chen, Z.Q.; George, A.D.; Yang, W.R. Effects of Middle-Late Permian sea-level changes and mass extinction on the formation of the Tieqiao skeletal mound in the Laibin area, South China. Aus. J. Earth Sci. 2009, 56, 745-763. [CrossRef]

90. Zhang, Z.; Wang, Y.; Zheng, Q.F. Middle Permian smaller foraminifers from the Maokou Formation at the Tieqiao section, Guangxi, South China. Palaeoworld 2015, 24, 263-276. [CrossRef]

91. Wardlaw, B.R.; Nestell, M.K. Latest Middle Permian conodonts from the Apache Mountains, West Texas. Micropaleontology 2010, 56, 149-184. [CrossRef]

92. Kennedy, W. Geology of Part of the Northwestern Apache Mountains, Southeast Culberson County, West Texas, U.S.A. Master's Thesis, The Univiversity of Texas Arlington, Arlington, TX, USA, 2009.

93. Haq, B.U.; Schutter, S.R. A chronology of Paleozoic sea-level changes. Science 2008, 322, 64-68. [CrossRef]

94. Shen, S.Z.; Yuan, D.X.; Henderson, C.M.; Wu, Q.; Zhang, Y.C.; Zhang, H.; Mu, L.; Ramezani, J.; Wang, X.D.; Lambert, L.L.; et al. Progress, problems and prospects: An overview of the Guadalupian Series of South China and North America. Earth-Sci. Rev. 2020, 211, 103412. [CrossRef]

95. Nestell, G.P.; Nestell, M.K. Late Capitanian (latest Guadalupian, Middle Permian) radiolarians from the Apache Mountains, West Texas. Micropaleontology 2010, 56, 7-68. [CrossRef]

96. Lambert, L.L.; Wardlaw, B.R.; Nestell, M.K.; Nestell, G.P. Latest Guadalupian (Middle Permian) conodonts and foraminifers from West Texas. Micropaleontology 2002, 48, 343-364. [CrossRef]

97. Henderson, C.M. Permian conodont biostratigraphy. In The Permian Timescale; Lucas, S.G., Shen, S.Z., Eds.; Geological Society: London, UK, 2018; Volume 450, pp. 119-142.

98. Wu, Q.; Ramezani, J.; Zhang, H.; Yuan, D.X.; Erwin, D.H.; Henderson, C.M.; Lambert, L.L.; Zhang, Y.C.; Shen, S.Z. High-precision $\mathrm{U}-\mathrm{Pb}$ zircon age constraints on the Guadalupian in West Texas, USA. Palaeogeogr. Palaeoclimatol. Palaeoecol. 2020, 548, 109668. [CrossRef]

99. Smith, B.P.; Larson, T.; Martindale, R.C.; Kerans, C. Impacts of basin restriction on geochemistry and extinction patterns: A case from the Guadalupian Delaware Basin, USA. Earth Planet. Sci. Lett. 2020, 530, 115876. [CrossRef]

100. Saitoh, M.; Ueno, Y.; Matsu'ura, F.; Kawamura, T.; Isozaki, Y.; Yao, J.Y.; Ji, Z.S.; Yoshida, N. Multiple sulfur isotope records at the end-Guadalupian (Permian) at Chaotian, China: Implications for a role of bioturbation in the Phanerozoic sulfur cycle. J. Asian Earth Sci. 2017, 135, 70-79. [CrossRef]

101. Saitoh, M.; Ueno, Y.; Isozaki, Y.; Nishizawa, M.; Shozugawa, K.; Kawamura, T.; Yao, J.X.; Ji, Z.S.; Takai, K.; Yoshida, N.; et al. Isotopic evidence for water-column denitrification and sulfate reduction at the end-Guadalupian (Middle Permian). Glob. Planet. Chang. 2014, 123, 110-120. [CrossRef]

102. Isozaki, Y.; Yao, J.X.; Ji, Z.S.; Saitoh, M.; Kobayashi, N.; Sakai, H. Rapid sea-level change in the Late Guadalupian (Permian) on the Tethyan side of South China: Litho- and biostratigraphy of the Chaotian section in Sichuan. Proc. Jpn. Acad. Ser. B 2008, 84, 344-353. [CrossRef] [PubMed]

103. Lai, X.L.; Wang, W.; Wignall, P.B.; Bond, D.P.G.; Jiang, H.S.; Ali, J.R.; John, E.H.; Sun, Y.D. Palaeoenvironmental change during the end-Guadalupian (Permian) mass extinction in Sichuan, China. Palaeogeogr. Palaeoclimatol. Palaeoecol. 2008, 269, 78-93. [CrossRef] 
104. Schoepfer, S.D.; Henderson, C.M.; Garrison, G.H.; Foriel, J.; Ward, P.D.; Selby, D.; Hower, J.C.; Algeo, T.J.; Shen, Y.N. Termination of a continent-margin upwelling system at the Permian-Triassic boundary (Opal Creek, Alberta, Canada). Glob. Planet. Chang. 2013, 105, 21-35. [CrossRef]

105. Schoepfer, S.D.; Henderson, C.M.; Garrison, G.H.; Ward, P.D. Cessation of a productive coastal upwelling system in the Panthalassic Ocean at the Permian-Triassic boundary. Palaeogeogr. Palaeoclimatol. Palaeoecol. 2012, 313-314, 181-188. [CrossRef]

106. Kenig, F.; Hudson, J.D.; Sinninghe Damste, J.S.; Popp, B.N. Intermittent euxinia: Reconciliation of a Jurassic black shale with its biofacies. Geology 2004, 32, 421-424. [CrossRef]

107. Algeo, T.J.; Kuwahara, K.; Sano, H.; Bates, S.; Lyons, T.; Elswick, E.; Hinnov, L.; Ellwood, B.; Moser, J.; Maynard, J.B. Spatial variation in sediment fluxes, redox conditions, and productivity in the Permian-Triassic Panthalassic Ocean. Palaeogeogr. Palaeoclimatol. Palaeoecol. 2011, 308, 65-83. [CrossRef]

108. Fujisaki, W.; Sawaki, Y.; Matsui, Y.; Yamamoto, S.; Isozaki, Y.; Maruyama, S. Redox condition and nitrogen cycle in the Permian deep mid-ocean: A possible contrast between Panthalassa and Tethys. Glob. Planet. Chang. 2019, 172, 179-199. [CrossRef]

109. Kuwahara, K.; Nakae, S.; Yao, A. Late Permian “Toishi-type" siliceous mudstone in the Mino-Tamba Belt. J. Geol. Soc. Japan 1991, 97, 1005-1008, In Japanese with English abstract. [CrossRef]

110. Kuwahara, K.; Yao, A. Late Permian radiolarian faunal change in bedded chert of the Mino Belt, Japan. New Osaka Micropaleontol. 2001, 12, 33-49, In Japanese with English abstract.

111. Yao, J.X.; Yao, A.; Kuwahara, K. Upper Permian biostratigraphic correlation between conodont and radiolarian zones in the Tamba-Mino Terrane, Southwest Japan. J. Geosci. Osaka City Univ. 2001, 44, 97-119.

112. Takahashi, S.; Yamakita, S.; Suzuki, N.; Kaiho, K.; Ehiro, M. High organic carbon content and a decrease in radiolarians at the end of the Permian in a newly discovered continuous pelagic section: A coincidence? Palaeogeogr. Palaeoclimatol. Palaeoecol. 2009, 271, 1-12. [CrossRef]

113. Kaiho, K.; Oba, M.; Fukuda, Y.; Ito, K.; Ariyoshi, S.; Gorjan, P.; Riu, Y.; Takahashi, S.; Chen, Z.Q.; Tong, J.N.; et al. Changes in depth-transect redox conditions spanning the end-Permian mass extinction and their impact on the marine extinction: Evidence from biomarkers and sulfur isotopes. Glob. Planet. Chang. 2012, 94-95, 20-32. [CrossRef]

114. Sugiyama, K. Lower and Middle Triassic radiolarians from Mt. Kinkazan, Gifu Prefecture, central Japan. Trans. Proc. Palaeontol. Soc. Jpn. 1992, 167, 1180-1223.

115. Takemura, A.; Sakai, M.; Sakamoto, S.; Aono, R.; Takemura, S.; Yamakita, S. Earliest Triassic radiolarians from the ARH and ARF sections on Arrow Rocks, Waipapa Terrane, Northland, New Zealand. In The Oceanic Permian/Triassic Boundary Sequence at Arrow Rocks (Oruatemanu) Northland, New Zealand; Sporli, K.B., Takemura, A., Hori, R.S., Eds.; GNS Science Monography: Lower Hutt, New Zealand, 2007; Volume 24, pp. 97-107.

116. Algeo, T.J.; Hinnov, L.; Moser, J.; Maynard, J.B.; Elswick, E.; Kuwahara, K.; Sano, H. Changes in productivity and redox conditions in the Panthalassic Ocean during the latest Permian. Geology 2010, 38, 187-190. [CrossRef]

117. Yamakita, S.; Kadota, N.; Kato, T.; Tada, R.; Ogihara, S.; Tajika, E.; Hamada, Y. Confirmation of the Permian/Triassic boundary in deep-sea sedimentary rocks; earliest Triassic conodonts from black carbonaceous claystone of the Ubara section in the Tamba Belt, Southwest Japan. J. Geol. Soc. Jpn. 1999, 105, 895-898. [CrossRef]

118. Isozaki, Y. Superanoxia Across the Permo-Triassic Boundary: Record in Accreted Deep-Sea Pelagic Chert in Japan. In Pangea: Global Environments and Resources; Embry, A.F., Beauchamp, B., Glass, D.J., Eds.; Canadian Society of Petroleum Geologists: Calgary, AB, Canada, 1994; Volume 17, pp. 805-812.

119. Kakuwa, Y. Evaluation of palaeo-oxygenation of the ocean bottom across the Permian-Triassic boundary. Glob. Planet. Chang. 2008, 63, 40-56. [CrossRef]

120. Takahashi, S.; Yamasaki, S.; Ogawa, Y.; Kimura, K.; Kaiho, K.; Yoshida, T.; Tsuchiya, N. Bioessential element-depleted ocean following the euxinic maximum of the end-Permian mass extinction. Earth Planet. Sci. Lett. 2014, 393, 94-104. [CrossRef]

121. Grasby, S.E.; Bond, D.P.G.; Wignall, P.B.; Yin, R.; Strachan, L.J.; Takahashi, S. Transient Permian-Triassic euxinia in the southern Panthalassa deep ocean. Geology 2021, 49, 889-893. [CrossRef]

122. Saitoh, M.; Ueno, Y.; Isozaki, Y.; Yoshida, N. Multiple sulfur isotope chemostratigraphy across the Permian-Triassic boundary at Chaotian, China: Implications for a shoaling model of toxic deep-waters. Isl. Arc 2021, 30, e12398. [CrossRef]

123. Isozaki, Y.; Shimizu, N.; Yao, J.X.; Ji, Z.S.; Matsuda, T. End-Permian extinction and volcanism-induced environmental stress: The Permian-Triassic boundary interval of lower-slope facies at Chaotian, South China. Palaeogeogr. Palaeoclimatol. Palaeoecol. 2007, 252, 218-238. [CrossRef]

124. Saitoh, M.; Ueno, Y.; Nishizawa, M.; Isozaki, Y.; Takai, K.; Yao, J.X.; Ji, Z.S. Nitrogen isotope chemostratigraphy across the Permian-Triassic boundary at Chaotian, Sichuan, south China. J. Asian Earth Sci. 2014, 93, 113-128. [CrossRef]

125. Thomazo, C.; Brayard, A.; Elmeknassi, S.; Vennin, E.; Olivier, N.; Caravaca, G.; Escarguel, G.; Fara, E.; Bylund, K.G.; Jenks, J.F.; et al. Multiple sulfur isotope signals associated with the late Smithian event and the Smithian/Spathian boundary. Earth-Sci. Rev. 2019, 195, 96-113. [CrossRef]

126. Vennin, E.; Olivier, N.; Brayard, A.; Bour, I.; Thomazo, C.; Escarguel, G.; Fara, E.; Bylund, K.G.; Jenks, J.F.; Stephen, D.A.; et al. Microbial deposits in the aftermath of the end-Permian mass extinction: A diverging case from the Mineral Mountains (Utah, USA). Sedimentology 2015, 62, 753-792. [CrossRef] 
127. Brayard, A.; Bylund, K.G.; Jenks, J.F.; Stephen, D.A.; Olivier, N.; Escarguel, G.; Fara, E.; Vennin, E. Smithian ammonoid faunas from Utah: Implications for Early Triassic biostratigraphy, correlation and basinal paleogeography. Swiss J. Palaeontol. 2013, 132, 141-219. [CrossRef]

128. Thomazo, C.; Vennin, E.; Brayard, A.; Bour, I.; Mathieu, O.; Elmeknassi, S.; Olivier, N.; Escarguel, G.; Bylund, K.G.; Jenks, J.; et al. A diagenetic control on the Early Triassic Smithian-Spathian carbon isotopic excursions recorded in the marine settings of the Thaynes Group (Utah, USA). Geobiology 2016, 14, 220-236. [CrossRef]

129. Clarkson, M.O.; Wood, R.A.; Poulton, S.W.; Richoz, S.; Newton, R.J.; Kasemann, S.A.; Bowyer, F.; Krystyn, L. Dynamic anoxic ferruginous conditions during the end-Permian mass extinction and recovery. Nature Commun. 2016, 7, 12236. [CrossRef]

130. Whitehouse, M.J. Multiple sulfur isotope determination by SIMS: Evaluation of reference sulfides for $\Delta^{33} \mathrm{~S}$ with observations and a case study on the determination of $\Delta^{36}$ S. Geostand. Geoanal. Res. 2013, 37, 19-33. [CrossRef]

131. Marin-Carbonne, J.; Rollion-Bard, C.; Bekker, A.; Rouxel, O.; Agangi, A.; Cavalazzi, B.; Wohlgemuth-Ueberwasser, C.C.; Hofmann, A.; McKeegan, K.D. Coupled Fe and S isotope variations in pyrite nodules from Archean shale. Earth Planet. Sci. Lett. 2014, 392, 67-79. [CrossRef]

132. Ushikubo, T.; Williford, K.H.; Farquhar, J.; Johnston, D.T.; Van Kranendonk, M.J.; Valley, J.W. Development of in situ sulfur four-isotope analysis with multiple Faraday cup detectors by SIMS and application to pyrite grains in a Paleoproterozoic glaciogenic sandstone. Chem. Geol. 2014, 383, 86-99. [CrossRef]

133. Harazim, D.; Virtasalo, J.J.; Denommee, K.C.; Thiemeyer, N.; Lahaye, Y.; Whitehouse, M.J. Exceptional sulfur and iron isotope enrichment in millimetre-sized, early Palaeozoic animal burrows. Sci. Rep. 2020, 10, 20270. [CrossRef]

134. Wang, W.; Hu, Y.L.; Muscente, A.D.; Cui, H.; Guan, C.G.; Hao, J.L.; Zhou, C.M. Revisiting Ediacaran sulfur isotope chemostratigraphy with in situ nanoSIMS analysis of sedimentary pyrite. Geology 2021, 49, 611-616. [CrossRef]

135. Nabhan, S.; Wiedenbeck, M.; Milke, R.; Heubeck, C. Biogenic overgrowth on detrital pyrite in ca. 3.2 Ga Archean paleosols. Geology 2016, 44, 763-766. [CrossRef]

136. Li, D.D.; Zhang, X.L.; Hu, D.P.; Li, D.; Zhang, G.J.; Zhang, X.; Ling, H.F.; Xu, Y.; Shen, Y. Multiple S-isotopic constraints on paleo-redox and sulfate concentrations across the Ediacaran-Cambrian transition in South China. Precambrian Res. 2020, 349, 105500. [CrossRef]

137. Chen, K.; Hu, D.P.; Zhang, X.L.; Zhu, H.; Sun, L.; Li, M.; Shen, Y. Minor $\Delta^{33}$ S anomalies coincide with biotic turnover events during the Great Ordovician Biodiversification Event (GOBE) in South China. Glob. Planet. Chang. 2020, 184, 103069. [CrossRef]

138. Luo, G.M.; Richoz, S.; van de Schootbrugge, B.; Algeo, T.J.; Xie, S.C.; Ono, S.; Summons, R.E. Multiple sulfur-isotopic evidence for a shallowly stratified ocean following the Triassic-Jurassic boundary mass extinction. Geochim. Cosmochim. Acta 2018, 231 , 73-87. [CrossRef]

139. Liu, J.; Antler, G.; Pellerin, A.; Izon, G.; Dohrmann, I.; Findlay, A.J.; Røy, H.; Ono, S.; Turchyn, A.V.; Kasten, S.; et al. Isotopically "heavy" pyrite in marine sediments due to high sedimentation rates and non-steady-state deposition. Geology 2021, 49, 816-821. [CrossRef]

140. Pasquier, V.; Bryant, R.N.; Fike, D.A.; Halevy, I. Strong local, not global, controls on marine pyrite sulfur isotopes. Sci. Adv. 2021, 7, eabb7403. [CrossRef] [PubMed] 